\title{
Non-Redfieldian mesopelagic nutrient remineralization in the eastern North Atlantic subtropical gyre
}

\author{
Bieito Fernández-Castro ${ }^{1}$ \\ Beatriz Mouriño-Carballido ${ }^{2}$ \\ Xosé Antón Álvarez-Salgado ${ }^{1}$
}

December 18, 2018

\section{Abstract}

The eastern boundary of the North Atlantic subtropical gyre (NASTG) receives organic materials produced in the nearby Canary upwelling system (CanUS), which has important implications for the metabolic balance of the region. Here we computed absolute geostrophic, Ekman and eddy diffusive transports and net budgets of oxygen, nitrate, and phosphate, with an inverse model applied to annual climatologies from the World Ocean Atlas 2013, in a large box covering the eastern boundary of the NASTG. The surface waters $(<100 \mathrm{~m})$ of the box exported $4.2 \pm 1.1 \mathrm{~mol} \mathrm{O}_{2} \mathrm{~m}^{-2} \mathrm{yr}^{-1}$ to the adjacent ocean and atmosphere, and imported $0.40 \pm 0.17 \mathrm{~mol} \mathrm{~N} \mathrm{~m}^{-2} \mathrm{yr}^{-1}$ and $22.2 \pm 9.5 \mathrm{mmol} \mathrm{P} \mathrm{m}^{-2} \mathrm{yr}^{-1}$ of nitrate and phosphate, respectively, indicating that net autotrophy prevailed in the euphotic waters of the eastern NASTG. The central, intermediate and deep waters (100 m-bottom) imported $6.7 \pm$ $3.3 \mathrm{~mol} \mathrm{O}_{2} \mathrm{~m}^{-2} \mathrm{yr}^{-1}$, and exported $1.05 \pm 0.35 \mathrm{~mol} \mathrm{~N} \mathrm{~m}^{-2} \mathrm{yr}^{-1}$ and $50.2 \pm 21.8 \mathrm{mmol} \mathrm{P} \mathrm{m}^{-2} \mathrm{yr}^{-1}$ of nitrate and phosphate, respectively, indicative of net remineralization. Mesopelagic remineralization rates exceeded epipelagic net community production, implying a net deficit of carbon and nutrients in the region. Remineralization occurred at high $\mathrm{N}: \mathrm{P}$ molar ratios $(\sim 28)$ in central waters, and thus, an excess nitrate $\left(\mathrm{DINxs}=\mathrm{NO}_{3}-16 \cdot \mathrm{PO}_{4}\right)$ was produced at a rate of $2.2 \pm 1.6 \times 10^{11} \mathrm{~mol} \mathrm{~N}$ $\mathrm{yr}^{-1}$. This excess nitrate was exported to the gyre interior, influencing the biogeochemistry of the whole NASTG and leaving the eastern margin with a strong nitrogen deficit, relative to carbon and phosphorus. According to the available literature, the organic carbon export from the CanUS could be sufficient to account for the carbon deficit, but the source of nitrogen remains elusive.

Keywords: Nutrient cycling; Remineralization; Metabolic Balance; Redfield Ratios; excess nitrate; Eastern North Atlantic subtropical gyre

Highlights:

- The upper ocean of the Eastern North Atlantic subtropical gyre is net autotrophic

- Mesopelagic remineralization exceeds net production in the epipelagic layer

- The full-depth metabolic balance is net heterotrophic

${ }^{1}$ Departamento de Oceanografía, Instituto de Investigacións Mariñas (IIM-CSIC), 36208, Vigo, Spain.

${ }^{2}$ Departamento de Ecoloxía e Bioloxía Animal, Universidade de Vigo, Universidade de Vigo, 36310 , Vigo, Spain.

Corresponding Author: Bieito Fernández-Castro, Departamento de Oceanografía, Instituto de Investigacións Mariñas (IIM-CSIC), 36310, Vigo, Spain. E-mail: bieitof@iim.csc.es, bieito. fernandez@uvigo.es 


\begin{tabular}{|c|c|c|c|}
\hline \multicolumn{4}{|c|}{ LIST OF ABBREVIATIONS } \\
\hline \multicolumn{2}{|c|}{ Geography and databases } & \multicolumn{2}{|l|}{ Currents } \\
\hline CanUS & Canary Upwelling System & $\mathrm{CC}$ & Canary Current \\
\hline CTZ & Coastal Transition Zone & CUC & Canary Upwelling Current \\
\hline CVFZ & Cape Verde Frontal Zone & $\mathrm{MC}$ & Mauritania Current \\
\hline NASTG & North Atlantic Subtropical Gyre & NEC & North Equatorial Current \\
\hline WOA13 & World Ocean Atlas 2013 & PUC & Poleward Undercurrent \\
\hline \multicolumn{2}{|c|}{ Water Masses } & \multicolumn{2}{|c|}{ Matter and transformations } \\
\hline NACW & North Atlantic Central Water & DIC & Dissolved Inorganic Carbon \\
\hline SACW & South Atlantic Central Water & DINxs & Excess nitrate tracer \\
\hline MW & Mediterranean Water & $\mathrm{NCP}$ & Net Community Production \\
\hline AAIW & Antarctic Intermediate Water & POC (DOC) & Particulate (Dissolved) Organic Carbon \\
\hline NADW & North Atlantic Deep Water & PON (DON) & Particulate (Dissolved) Organic Nitrogen \\
\hline LDW & Lower Deep Water & & \\
\hline
\end{tabular}

- High N:P remineralization ratios result in significant excess nitrate production

- The region exports excess nitrate and it is strongly nitrogen-deficient

\section{Introduction}

When organic matter production by planktonic communities exceeds respiration in the euphotic zone, a fraction of this biogenic material is exported to the deep ocean where it is remineralized to inorganic carbon and nutrients (Sarmiento and Gruber, 2006). This downward carbon and nutrients flux mediated by the marine biota is referred as the biological carbon pump. In open ocean oligotrophic regions, the biological carbon pump has been historically regarded as a one-dimensional process (Sarmiento and Gruber, 2006). Accordingly, organic matter export is largely dominated by sinking particles (Eppley and Peterson, 1979), and the cycle is closed when nutrients are resupplied to the euphotic zone by downgradient turbulent diffusion (Lewis et al., 1986).

Recent studies pointed out that lateral fluxes of inorganic and organic nutrients can be essential to sustain new production in the open ocean (Jenkins and Doney, 2003, Torres-Valdés et al., 2009, Palter et al., 2013, Reynolds et al., 2014, Letscher et al., 2016, Vidal et al., 2018), and to redistribute organic carbon from regions of excess production (i.e. continental margins) to regions of intense remineralization and burial (Walsh, 1991, Helmke et al., 2005, Inthorn et al., 2006), challenging the one-dimensional view of the biological carbon pump. The role of lateral fluxes in the biogeochemistry of the oligotrophic oceans is potentially more relevant in the eastern margins of the subtropical gyres, influenced by neighboring eastern Boundary Upwelling systems (EBUS). Those highly productive continental margins (Carr, 2002) are connected dynamically with the adjacent oligotrophic ocean through active coastal transition zones (CTZ), exchanging nutrients and organic matter (Barth, 2002, Pelegrí et al., 2005, 2006, Liu et al., 2010, Nagai et al., 2015, Lovecchio et al., 2017).

The Canary upwelling system (CanUS), located at the eastern boundary of the North Atlantic subtropical gyre (NASTG) between 9 and $33^{\circ} \mathrm{N}$ (Valdés and Déniz-González, 2015), is one of the most 
productive EBUS worldwide, with an annual primary production of $330 \mathrm{Tg}$ C (Carr, 2002). Dedicated studies have demonstrated an intense offshore export of particles and organic carbon from the productive shelf toward the open ocean (Pelegrí et al., 2005), mediated by a system of semi-permanent and intermittent filaments (Gabric et al., 1993, Bory et al., 2001, García-Muñoz et al., 2004, 2005, Álvarez-Salgado et al., 2007, Santana-Falcón et al., 2016), mesoscale eddies shed from the Canary Current flow across the Canary Islands (Barton et al., 2004, Sangrà et al., 2009), together with the Ekman and thermohaline circulation (Alonso-González et al., 2009). The organic carbon flux reaches up to several hundreds of kilometers offshore (Neuer et al., 2002, Helmke et al., 2005), and a part of it can escape heterotrophic processes in the CTZ and ultimately pour into the oligotrophic NASTG, where it fuels mesopelagic respiration (Álvarez-Salgado et al., 2007, Alonso-González et al., 2009, Lovecchio et al., 2017, 2018).

The supply of materials from its boundaries is known to influence the metabolic balance and the biogeochemical transformations in the eastern subtropical North Atlantic (eg. Doval et al., 2001, Hansell et al., 2004b, Torres-Valdés et al., 2009, Landolfi et al., 2016). It has been suggested that the flux of organic materials could explain the euphotic zone net heterotrophic metabolic balance of the eastern NASTG found in in vitro measurements (Duarte and Agustí, 1998, Duarte et al., 2001, Serret et al., 2015). On the other hand, although biogeochemical and model estimates indicate that the euphotic layer is net autotrophic (Neuer et al., 2007, González-Dávila et al., 2007, Letscher and Moore, 2017), they also pointed out that the full-depth metabolic balance of the (eastern) NASTG is net heterotrophic (Hansell et al., 2004b, Lovecchio et al., 2017). In this regard, other modelling studies have shown that dissolved organic matter advected from the productive eastern flank of the NASTG could be utilized in the euphotic zone, and sustain a large fraction of the particulate organic nitrogen and phosphorus export to the deep ocean (Roussenov et al., 2006, Torres-Valdés et al., 2009). Finally, the NASTG is characterized by significant deviations from the Redfield stoichiometry in the thermocline nutrient pools, showing a nitrate $\left(\mathrm{NO}_{3}\right)$ excess over the expected nitrate:phosphate $\left(\mathrm{PO}_{4}\right)$ ratio of $16($ Michaels et al., 1996, Gruber and Sarmiento, 1997, Zamora et al., 2010). This anomaly was initially attributed to the effect of biological nitrogen fixation (Capone et al., 2005). However, recent studies also pointed out to the input of non-Redfield organic matter from the gyre boundaries and subsequent recycling, as a first-order contributor to this feature (Hansell et al., 2007, Landolfi et al., 2008, Kähler et al., 2010).

Despite this evidence, previous studies addressing the connection between the eastern NASTG and the CanUS were focused mainly on organic carbon fluxes, remineralization and export (Neuer et al., 2002, Arístegui et al., 2003b, Helmke et al., 2005, Alonso-González et al., 2009, Lovecchio et al., 2017), while the transport of organic and inorganic nutrients and subsequent biogeochemical transformations in this area and their influence on the biogeochemistry of the NASTG are less well characterized (Pelegrí et al., 2006). Here, we use an inverse modelling approach (eg. Rintoul and Wunsch, 1991, Ganachaud and Wunsch, 2002, Hansell et al., 2004b), applied to climatological data from the World Ocean Atlas 2013 in a box located in the eastern margin of the NASTG, between 18.5 and $30.5^{\circ} \mathrm{N}$ and 19.5 and $27.5^{\circ} \mathrm{W}$, to adjust the mass transport and to calculate oxygen, nitrate and phosphate fluxes and budgets (Figure 1). The main goal was to determine the rates of biogeochemical transformations and the metabolic balance for the different elements in photic and aphotic waters. By doing so, we seek to improve our knowledge of the biogeochemistry of this region by indirectly assessing the role of the organic 


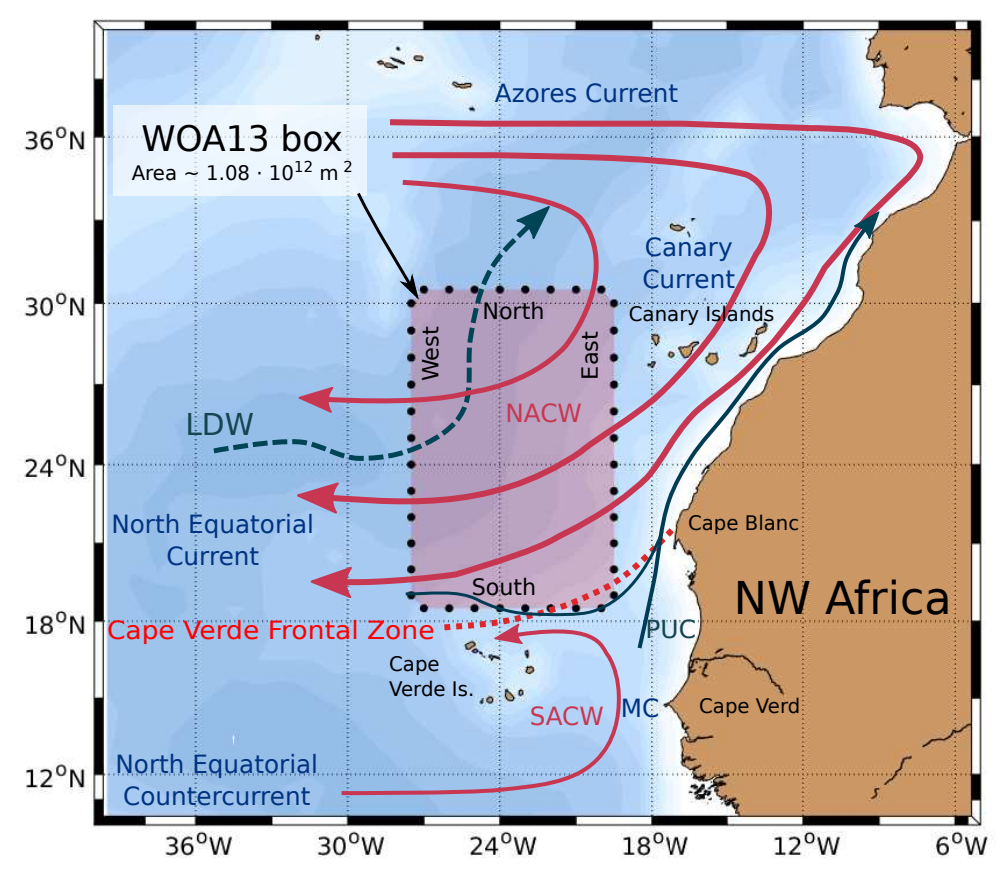

Figure 1: Map of the study area. The black dots indicate the position of the node-pairs delimiting the WOA13 (World Ocean Atlas 2013) box. The main geographic, oceanographic features and currents are indicated. Red arrows represent surface and thermocline currents: Azores Current, Canary Current, North Equatorial Current, North Equatorial Counter Current and Mauritania Current (MC); the solid dark blue line, the Poleward Undercurrent (PUC); and the dashed dark blue line, the deep flow of the Lower Deep Water (LDW). NACW and SACW are the North and South Atlantic Central waters, respectively. The red dashed line indicates the approximate position of the Cape Verde Front. Adapted from Pelegrí and Peña-Izquierdo (2015).

materials imported from the CanUS. Furthermore, the stoichiometry of the transformation processes and the composition of the produced and degraded organic material were investigated, and the contribution of the eastern NASTG to the production of excess nitrate in the North Atlantic was quantified.

\section{Methods}

\subsection{Study area}

The box was chosen to match the study area of Hernández-Guerra et al. (2005) and Alonso-González et al. (2009), who also used an inverse model to evaluate the mass and particulate organic carbon (POC) transport, respectively, in the Canary Current (CC) region (Figure 1). The box is located mostly in deep waters of the eastern margin of the NASTG, away from the main area of influence of upwelling filaments and eddies. The upper ocean circulation in the area is dominated by the $\mathrm{CC}$, that flows southsouthwestwards through the Canary Archipelago. The southward flow is enhanced close to the African coast by the upwelling jet, forming the Canary Upwelling Current (CUC) which represents the boundary of the NASTG (Pelegrí et al., 2005, Pelegrí and Peña-Izquierdo, 2015). However, this coastallyenhanced flow is located eastwards of the box area. Around $20^{\circ} \mathrm{N}$, the $\mathrm{CC}$ feeds its water into the westward flow of the North Equatorial Current (NEC) (Figure 1). South of the NEC, The Cape Verde 
Frontal zone (CVFZ) separates the area of the influence of the warmer and saltier North Atlantic Central Water (NACW) and the cooler and fresher South Atlantic Central Water (SACW), at the thermocline depths (Zenk et al., 1991, Pérez-Rodríguez et al., 2001). In this area, the northeastward flow of the Mauritania Current (MC), south of our box, converges with the NEC, resulting in enhanced nutrient supply owing to the high nutrient content of the SACW (Auger et al., 2016, Lovecchio et al., 2017). This circulation pattern gives rise to the Cape Blanc giant filament, an area of intense primary productivity and offshore carbon export (Gabric et al., 1993, Helmke et al., 2005, Bory et al., 2001, Meunier et al., 2012). A return flow associated with the CUC, the Poleward Undercurrent (PUC), takes place along the African coast at intermediate levels carrying Antarctic Intermediate Water (AAIW) northestwards (Pelegrí and Peña-Izquierdo, 2015, Pérez et al., 2001) (Figure 1). At the deepest-most levels of the eastern North Atlantic basin a weak, northward flow of the modified Antarctic Bottom water (AABW), that enters the Canary Basin through a gap at $38^{\circ} \mathrm{W}$ in the Cape Verde Ridge after spreading into the eastern basin of the North Atlantic through the Romanche and Vema Fractures (McCartney et al., 1991), is expected (Figure 1). This water body is usually referred as the Lower Deep Water (LDW). A large volume of NADW lies at the deep levels, between the AAIW and the LDW, generally associated to weak transports (Hernández-Guerra et al., 2005).

\subsection{The inverse model: transport terms and constraints}

The temperature (Locarnini et al., 2013), salinity (Zweng et al., 2013), oxygen (Garcia et al., 2013a) and nutrients (Garcia et al., 2013b) distributions at the box boundaries were obtained from the World Ocean Atlas 2013 (WOA13) objectively analyzed long-term climatology (https://www. nodc noaa. gov/OC5/woa13/). A total number of 41 nodes were selected from the $1^{\circ} \times 1^{\circ}$ WOA13 grid, spanning a surface area of $A^{S}=1.08 \times 10^{12} \mathrm{~m}^{2}$. (Figure 1). All the variables have been linearly interpolated to a vertical grid with an uniform resolution of $1 \mathrm{~m}$.

Geostrophic velocities were calculated for every node-pair by integrating the thermal wind equations, using the neutral density ( $\gamma_{n}$ Jackett and McDougall, 1997) profiles derived from temperature and salinity WOA13 fields. In order to calculate the transport through the bottom triangles, the $\gamma_{n}$ profile reaching a shallower depth of each node pair was extended to the maximum depth of the deeper profile by keeping constant the density difference between both profiles. Climatological Ekman transport was computed from the NCEP/NCAR Reanalysis monthly means of wind speed provided by NOAA/OAR/ESRL PSD (https://www . esrl . noaa.gov/psd/), and added as an uniform velocity in the upper $50 \mathrm{~m}$. Lateral eddy diffusion of tracers was modelled as the product of the horizontal tracer gradient perpendicular to the box face $\left(\partial_{x} C\right)$ and an eddy diffusion coefficient $\left(K_{\mathrm{h}}\right)$. The horizontal gradients were calculated by centered differences using the adjacent points of the WOA 2013 climatology. The eddy diffusion coefficient was calculated following the Visbeck et al. (1997) parameterization as:

$$
K_{\mathrm{h}}=\alpha \frac{M^{2}}{N} l^{2}
$$

where $M^{2}$ is the absolute value of the horizontal stratification vector $\left(\mathbf{M}^{2}=-g / f\left(\partial_{x} \gamma_{n}, \partial_{y} \gamma_{n}\right)\right)$, where $g$ is gravity; $N$ is the vertical stratification $\left(N^{2}=-g / f \partial_{z} \gamma_{n}\right) ; l$ is a characteristic length-scale here taken 
as the distance between two grid points $\left(l \sim 1^{\circ} \sim 100 \mathrm{~km}\right)$, which is close to the local first baroclinic Rossby radius (Chelton et al., 1998), and $\alpha$ is an adjustable constant.

The reference velocities $\left(v_{\text {ref }}^{i}\right)$, required to compute absolute geostrophic velocities, and the $\alpha$ factor were calculated using a linear inverse approach (Jackson, 1979, Mercier, 1986), following previous works in the study and nearby regions, using both cruise-based (Hernández-Guerra et al., 2005, Machín et al., 2006, Vélez-Belchí et al., 2016) and climatological data (Carracedo et al., 2014). The inverse procedure consists on re-evaluating a set of a priori values for the problem unknowns $\left(\mathbf{X}=\left\{\alpha, v_{\mathrm{ref}}^{1}, \ldots, v_{\mathrm{ref}}^{N}\right\}\right.$, where $N=40$ is number of node-pairs) by imposing a number of physically meaningful constraints $\left(\mathbf{f}=f^{k}\right)$. The optimal solution of the inverse problem minimizes the following function:

$$
\left(\mathbf{X}-\mathbf{X}_{0}\right)^{T} \cdot \mathbf{E}_{o}^{-1} \cdot\left(\mathbf{X}-\mathbf{X}_{0}\right)+f(\mathbf{X})^{T} \cdot \mathbf{E}_{c}^{-1} \cdot f(\mathbf{X}),
$$

where $\mathbf{X}_{0}$ is the vector of a priori values of the problem unknowns, $\mathbf{E}_{0}$ is their a priori covariance matrix, $\mathbf{f}$ is the vector of constraints, and $\mathbf{E}_{c}$ the corresponding covariance matrix. The analytical solution for this optimization problem is given by:

$$
\mathbf{X}^{\star}=\mathbf{X}_{0}-\mathbf{E}_{0} \cdot \mathbf{F}^{T} \cdot\left(\mathbf{F} \cdot \mathbf{E}_{0} \cdot \mathbf{F}^{T}+\mathbf{E}_{c}\right)^{-1} \cdot f\left(\mathbf{X}_{0}\right)
$$

where $\mathbf{F}$ is the model matrix of partial derivatives, $\mathbf{F}^{k i}=\frac{\partial f^{k}}{\partial X^{i}}$.

The initial-guess reference velocities were set to zero and assigned to a no-motion level at the interface separating the deep and bottom waters $\left(\gamma_{n}=28.072 \mathrm{~kg} \mathrm{~m}^{-3}\right)$, according to previous studies in the North Atlantic (Ganachaud, 2003, Hernández-Guerra et al., 2005, Alonso-González et al., 2009). An a priori error of $\pm 0.2 \mathrm{~cm} \mathrm{~s}^{-1}$ was assigned to the reference velocities and they were assumed to be uncorrelated. The smoothing of the thermohaline gradients, implied by the use of climatologies, results in weaker geostrophic velocities compared to cruise-based studies (Carracedo et al., 2014). This fact justifies the choice of a relatively small value for the reference velocity variance, lower than that used on cruise-based studies (eg. Hernández-Guerra et al., 2005, Pérez-Hernández et al., 2013). The initial-guess value for $\alpha$ was 0.13 following Bryan et al. (1999), with an assumed uncertainty of $100 \%$.

The constraints imposed to the inverse model were mass, salt and heat conservation. In practice, the Boussinesq approximation was followed throughout the calculations and, hence, volume and not mass conservation was imposed. The model constraints were formulated as:

$$
\begin{aligned}
f^{1}=\sum_{i j}\left(v^{i j}+v_{\text {ref }}^{i}\right) A^{i j}-(E-P) & =0 \\
f^{2}=\sum_{i j}\left(v^{i j}+v_{\text {ref }}^{i}\right) \rho^{i j} S^{i j} A^{i j}-\sum_{i j} K_{h}^{i j} \rho^{i j} \partial_{x} S^{i j} A^{i j} & =0 \\
f^{3}=\sum_{i j}\left(v^{i j}+v_{\text {ref }}^{i}\right) \rho^{i j} c_{P}^{i j} \theta^{i j} A^{i j}-\sum_{i j} K_{h}^{i j} \rho^{i j} c_{P}^{i j} \partial_{x} \theta^{i j} A^{i j}-F_{\text {Heat }}^{\text {sea-air }} & =0
\end{aligned}
$$

where $i$ and $j$ are the node-pair and depth coordinates, respectively; $v^{i j}$ are the geostrophic velocities referenced to $\gamma_{n}=28.072 \mathrm{~kg} \mathrm{~m}^{3} ; A^{i j}$ is the bin area (depth times distance between nodes); (E-P) is the evaporation minus precipitation flux; $\rho$ is the in situ density; $S$, salinity; $c_{p}$, the specific heat capacity 
Table 1: Net mass, salt, heat, oxygen, nitrate and phosphate horizontal transports into the model box (positive means net flux into the box). The first column reports the net fluxes obtained using the initial guess reference velocities (No motion level at $\gamma_{n}=28.072 \mathrm{~kg} \mathrm{~m}^{-3}$ ), the second column shows the constraints imposed to the inverse model, and the third column represents the net fluxes obtained with the optimal inverse solution. Number in brackets are the contribution of baroclinic eddies (horizontal diffusion).

\begin{tabular}{lrlll}
\hline & Units & Initial & Constraint & Final \\
\hline Mass & $\mathrm{Sv}$ & 1 & $0.05 \pm 1$ & $0.032 \pm 0.022$ \\
Salt & $10^{6} \mathrm{~kg} \mathrm{~s}^{-1}$ & $35.84(-0.53)$ & $0 \pm 1$ & $0.55 \pm 0.29(-0.35 \pm 0.55)$ \\
Heat & $10^{12} \mathrm{~W}$ & $-20.2(-5.9)$ & $3.9 \pm 28.0$ & $-35.9 \pm 9.9(-3 . \pm 6.0)$ \\
\hline Oxygen & $\mathrm{kmol} \mathrm{O}_{2} \mathrm{~s}^{-1}$ & $437(-56)$ & & $200 \pm 109(-37 \pm 57)$ \\
Nitrate & $\mathrm{kmol} \mathrm{s} \mathrm{s}^{-1}$ & $-0.90(3.62)$ & & $-22.3 \pm 11.9(2.3 \pm 3.7)$ \\
Phosphate & $\mathrm{kmol} \mathrm{P} \mathrm{s}^{-1}$ & $-0.06(-0.03)$ & & $-0.95 \pm 0.70(-0.04 \pm 0.06)$ \\
\hline
\end{tabular}

of seawater; $\theta$, the potential temperature; and $F_{\text {Heat }}^{\text {sea-air }}$, the sea-air heat flux (positive towards the atmosphere). Thus, the net evaporation-precipitation flux (net heat) to the atmosphere must be compensated by a mass (heat) transport convergence into the box. Mass and tracer fluxes were defined as positive into the box. This was implementing by including a factor of -1 in the $A^{i j}$ term for the North and East faces.

Climatological evaporation-precipitation and heat fluxes were calculated using the NCEP/NCAR Reanalysis monthly means of air-sea fluxes. Evaporation dominated over precipitation inside the box, resulting in a net climatological freshwater flux of $0.048 \pm 0.012 \mathrm{~Sv}\left(1 \mathrm{~Sv}=10^{6} \mathrm{~m}^{3} \mathrm{~s}^{-1}\right)$ to the atmosphere (Supplementary Figure A1). Due to the influence of the coastal upwelling over the western African coast, the net heat flux was directed from the atmosphere to the ocean in the eastern side of the box, while the ocean experienced a net heat loss in the western side (Supplementary Figure A1). As a result of this interplay, a weak net mean heat loss by the ocean of $3.6 \pm 12.4 \mathrm{~W} \mathrm{~m}^{-2}\left(3.9 \pm 14 \times 10^{12}\right.$ W) was computed, where the error is the standard deviation computed for the database nodes inside the box.

With this information, we imposed a mass imbalance of $0.05 \mathrm{~Sv}$ to which we assigned an initial error of $1 \mathrm{~Sv}$; and a heat imbalance of $3.9 \times 10^{12} \mathrm{~W}$, with an error of $28.0 \times 10^{12} \mathrm{~W}$, twice the standard deviation. A more strict salt conservation was required by setting the initial error to $1 \times 10^{6} \mathrm{~kg} \mathrm{~s}^{-1}$ (Table 1). The initial errors for mass and salt conservation were chosen to be the same as in Carracedo et al. (2014). Random perturbations of the a priori values for the reference velocities and constraints (2000 realizations) were used to calculate the error covariance matrix of the optimal $\alpha$ and reference velocities $\left(\mathbf{E}^{\star}\right)$. In this way, the sensitivity of the optimal solution to the choice of the particular value of the constraints, within the considered error bars, was implicitly taken into account. Prior to inversion, the net mass, salt and heat imbalances amounted $1 \mathrm{~Sv}, 36.1 \times 10^{6} \mathrm{~kg} \mathrm{~s}^{-1}$ and $-20.2 \times 10^{12} \mathrm{~W}$. After inversion, the mass and salt imbalances were reduced to $0.032 \pm 0.022 \mathrm{~Sv}$, slightly lower than the climatological freshwater flux to the atmosphere, and $0.55 \pm 0.29 \times 10^{6} \mathrm{~kg} \mathrm{~s}^{-1}$, respectively (Table 1). The optimized heat imbalance changed slightly to $-35.9 \pm 9.9 \times 10^{12} \mathrm{~W}$, implying a net heat flux from the atmosphere to the ocean. 


\subsection{Heat, salt, oxygen and nutrient transports and budgets}

The water column was divided into 12 layers $(M=12)$ delimited by neutral density isolines. The neutral density levels roughly separated the different water masses present in the section and were chosen following previous works in the North Atlantic (Ganachaud, 2003, Hernández-Guerra et al., 2005). The upper layer $\left(\gamma_{n}<26.33 \mathrm{~kg} \mathrm{~m}^{-3}\right)$ corresponded to surface waters; the next three layers $\left(26.33<\gamma_{n}<27.38\right.$ $\mathrm{kg} \mathrm{m}^{-3}$ ) included the thermocline waters, i.e. the North and South Atlantic Central Waters (NACW, $\mathrm{SACW})$; the next three $\left(27.38<\gamma_{n}<27.922 \mathrm{~kg} \mathrm{~m}^{-3}\right)$ the intermediate waters, i.e. the Mediterranean Water (MW) and the Antarctic Intermediate Water (AAIW); the next four $\left(27.922<\gamma_{n}<28.072\right.$ $\left.\mathrm{kg} \mathrm{m}^{-3}\right)$ the North Atlantic Deep Water (NADW); and the last level $\left(\gamma_{n}>28.72 \mathrm{~kg} \mathrm{~m}^{-3}\right)$ corresponded to the Lower Deep Water (LDW).

Net transports of mass, heat, salt, dissolved oxygen and nutrients (nitrate, $\mathrm{NO}_{3}$; and phosphate, $\mathrm{PO}_{4}$ ) were computed for each neutral density layer. The net transport in a neutral density layer $(l=1, \ldots, M)$ includes the horizontal transport across the lateral boundaries (horizontal advection and diffusion, hA and $\mathrm{hD}$, respectively, Eq. 7) and the vertical advective (vA, Eq. 8) and diffusive transport (vD, Eq. 9) across the lower $(l-0.5)$ and upper $(l+0.5)$ boundaries. Net budgets of the different tracers can also include sea-air exchange $\left(F_{C}^{\text {sea-air }}\right)$ in the upper layer and a biogeochemical source term for oxygen and nutrients $\left(J_{C}^{\text {bio }}\right)$ in all layers:

$$
\begin{aligned}
T_{\text {Net, } C}^{l}= & T_{\mathrm{hA}}^{l}+T_{\mathrm{hD}}^{l} \\
& +T_{\mathrm{vA}}^{l-0.5} \rho^{l-0.5} C^{l-0.5}-T_{\mathrm{vA}}^{l-0.5} \rho^{l+0.5} C^{l+0.5} \\
& -T_{\mathrm{vD}}^{l-0.5}\left(\rho^{l} C^{l}-\rho^{l-1} C^{l-1}\right)+T_{\mathrm{vD}}^{l+0.5}\left(\rho^{l+1} C^{l+1}-\rho^{l} C^{l}\right) \\
& \left(-F_{C}^{\text {sea-air }}+J_{C}^{l, \text { bio }}\right)
\end{aligned}
$$

where $T_{\mathrm{hA}}^{l}=\sum_{i, j}^{\gamma_{n}^{l}}\left(v^{i j}+v_{\mathrm{ref}}^{i}\right) A^{i j} \rho^{i j} C^{i j}$ and $T_{\mathrm{hD}}^{l}=-\sum_{i, j}^{\gamma_{n}^{l}} K_{\mathrm{h}}^{i j} A^{i j} \rho^{i j} \partial_{x} C^{i j}$ are the horizontal advective and diffusive transport in the $l$-neutral density level, $C$ and $\rho$ are the property concentrations $\left(C=c_{P} \theta\right.$, in the case of heat) and the in situ density for a layer or interface, and $T_{\mathrm{vA}}$ and $T_{\mathrm{vD}}$ are the vertical advective and diffusive transports in $\mathrm{m}^{3} \mathrm{~s}^{-1}$. These transports can be related to the averaged vertical velocities, $w=T_{\mathrm{vA}} / A^{S}$, and diffusivities, $K_{\mathrm{vD}}=T_{\mathrm{vD}} \cdot \Delta d / A^{S}$, where $\Delta d$ is the vertical distance between the center of two consecutive neutral density layers and $A^{S}$ is the box surface area.

Instead of diagnosing $w$ and $K_{\mathrm{v}}$ by including them as unknowns in the inverse box model, they were calculated exactly a posteriori by solving the system (Eq. 7-10) to ensure conservation of mass $\left(T_{\text {Net, Mass }}^{l}=0, l=1, \ldots, M\right)$ in all density layers, and heat conservation $\left(T_{\text {Net, Heat }}^{l}=0, l=2, \ldots, M\right)$ in all density layers except the surface, respectively for $w$ and $K_{\mathrm{v}}$. The remaining imbalance in the upper layer was attributed to air-sea exchange. With the condition of zero flux across the bottom boundary, both systems have the same numbers of unknowns and equations and can be solved exactly. This method has the advantage that the solution is not dependent on the $a$ priori estimates, which are not required.

The biogeochemical source terms for oxygen and nutrients were inferred by assuming steady state. In the model layers that are not in contact with the atmosphere, the biogeochemical source term was calculated as minus the net transport for this layer: $J_{C}^{l, \text { bio }}=-T_{\text {Net, } C}^{l}$. In the surface layer, the air-sea flux of oxygen (air-sea gas exchange) and nutrients (atmospheric deposition) were also considered. The errors 
Table 2: Oxygen air-sea exchange flux $\left(\mathrm{F}_{\mathrm{O}_{2}}^{\text {sea-air }}\right.$, mol $\left.\mathrm{O}_{2} \mathrm{~m}^{-2} \mathrm{y}^{-1}\right)$ computed inside the model box using different parameterizations of the gas transfer velocity $\left(k_{w}\right)$ and bubble-induced flux.

\begin{tabular}{lr}
\hline$k_{w}$ Parameterization & $\begin{array}{r}\mathrm{F}_{\mathrm{O}_{2}}^{\text {sea-air }} \\
\left(\mathrm{mol} \mathrm{O}_{2} \mathrm{~m}^{-2} \mathrm{y}^{-1}\right)\end{array}$ \\
\hline Liss and Melivat (1986) and Woolf and Thorpe (1991) & 2.15 \\
Wanninkhof (1992) and Woolf and Thorpe (1991) & 4.66 \\
Wanninkhof et al. (1999) and Woolf and Thorpe (1991) & 3.23 \\
Nightingale et al. (2000) and Woolf and Thorpe (1991) & 3.39 \\
Ho et al. (2006) and Woolf and Thorpe (1991) & 3.17 \\
Wanninkhof et al. (2009) and Woolf and Thorpe (1991) & 2.87 \\
Liang et al. (2013) & 4.83 \\
\hline Mean $\pm \mathrm{SD}$ & $3.47 \pm 0.90$ \\
\hline
\end{tabular}

associated with all the budgets terms, including the biological rates and $T_{\mathrm{vA}}$ and $T_{\mathrm{vD}}$, were computed as the standard deviation of 2000 realizations derived from random perturbations of the optimal $\alpha$ and reference velocities generated using the covariance matrix $\mathbf{E}^{\star}$.

\subsection{Oxygen and nutrient atmospheric fluxes}

The atmospheric deposition fluxes of nitrate and phosphate into the box were obtained from Duce et al. (2008), Mahowald et al. (2008) and Jickells et al. (2017), while the mean air-sea oxygen flux was calculated as the product of the gas transfer velocity $\left(k_{W}\right)$ and the oxygen excess over the saturation at the local atmospheric pressure $(p)$ :

$$
F_{\mathrm{O}_{2}}^{\text {sea-air }}=k_{W} \cdot\left(\mathrm{O}_{2}-\left(p / p_{0}\right)\left(\mathrm{O}_{2}^{\text {sat }}+\mathrm{O}_{2}^{\text {sat,bub }}\right)\right)
$$

where $\mathrm{O}_{2}^{\text {sat }}$ is the oxygen saturation (dependent on seawater temperature and salinity) at standard atmospheric pressure, and $\mathrm{O}_{2}^{\text {sat,bub }}=0.01\left(w / w_{0}\right)^{2}$ is the saturation correction for bubble injection (Woolf and Thorpe, 1991), where $w$ is the wind speed in $\mathrm{ms}^{-1}$ and $w_{0}=9 \mathrm{~m} \mathrm{~s}^{-1}$. Monthly climatological values of atmospheric pressure and wind speed were obtained from the NCEP-reanalysis database, while temperature, salinity and oxygen values were obtained from the WOA13 monthly climatologies. Those were averaged, for each month, over the mixed layer (determined using a density difference criterion, $\Delta \sigma_{\theta}=0.25 \mathrm{~kg} \mathrm{~m}^{-3}$ ) of all the grid points inside the box. Thus, monthly air-sea fluxes were computed and finally averaged to report a mean annual value.

The air-sea fluxes obtained can be sensitive to the choice of the parameterization of the piston velocity, usually formulated as a polynomial function of wind speed (Wanninkhof et al., 2009). A number of different parameterizations were used here to account for this uncertainty (see Table 2). The net oxygen exchange is also sensitive to the parameterization of the bubble processes (Emerson and Bushinsky, 2016). For this reason the recent parameterization of equilibrium and bubble-induced fluxes by Liang et al. (2013) was also employed. The calculated air-sea oxygen fluxes ranged from 2.15 to $4.85 \mathrm{~mol} \mathrm{O}_{2} \mathrm{~m}^{-2} \mathrm{yr}^{-1}$. The mean value of the different estimates \pm one standard deviation $(3.47 \pm 0.90$ $\mathrm{mol} \mathrm{O}_{2} \mathrm{~m}^{-2} \mathrm{yr}^{-1}$ ) was used for the budget calculations. 
Table 3: Chemical composition of the organic products of synthesis and early degradation of marine phytoplankton according to Fraga et al. (1998). The percentages (in weight) of each group correspond to the stoichiometry of synthesis and early degradation of marine phytoplankton $\left(-\mathrm{O}_{2}: \mathrm{C}: \mathrm{N}: \mathrm{P}=150: 106: 16: 1\right)$.

\begin{tabular}{llrr}
\hline & Chemical formula & Weight $\left(\mathrm{g} \mathrm{mol}^{-1}\right)$ & Contribution in weight (\%) \\
\hline Phosphorus compounds (Pho) & $\mathrm{C}_{45} \mathrm{H}_{76} \mathrm{O}_{31} \mathrm{~N}_{12} \mathrm{P}_{5}$ & 1435 & 12 \\
Proteins (Pro) & $\mathrm{C}_{147} \mathrm{H}_{228} \mathrm{O}_{46} \mathrm{~N}_{40} \mathrm{~S}$ & 3316 & 47 \\
Carbohydrates (Cbh) & $\mathrm{C}_{6} \mathrm{H}_{10} \mathrm{O}_{5}$ & 162 & 24 \\
Lipids (Lip) & $\mathrm{C}_{53} \mathrm{H}_{89} \mathrm{O}_{6}$ & 821 & 16 \\
\hline
\end{tabular}

Furthermore, in order to determine the relative importance of biological and thermal forcing on the sea-air oxygen flux, the thermally-driven flux was determined according to Keeling et al. (1993):

$$
F_{\text {thermal-O }}^{\text {sea-air }}=\frac{\partial\left[\mathrm{O}_{2}\right]_{\text {sat }}^{\circ}}{\partial T} \frac{F_{\text {heat }}^{\text {sea-air }}}{c_{P}}
$$

All the variables in this calculation were obtained using the local temperature and salinity values for the upper layer of the box model.

\subsection{Stoichiometric model}

Once the rates of transformation for oxygen $\left(J_{\mathrm{O}_{2}}^{\text {bio }}\right)$ and nutrients $\left(J_{\mathrm{NO}_{3}}^{\text {bio }}, J_{\mathrm{PO}_{4}}^{\text {bio }}\right)$ have been determined, the average biogeochemical composition of the produced/remineralized material can be estimated from the biogeochemical formulas of the products of synthesis and early degradation of marine phytoplankton (eg. Álvarez-Salgado et al., 2014). Assuming that changes in the chemical composition of marine phytoplankton are due to variations in the proportions of phosphorus compounds (Pho), proteins (Prt), carbohydrates (Cbh) and lipids (Lip) rather than variations in the molecular formula of each group, it is possible to estimate their proportions as proposed by Fraga et al. (1998). Based on the elemental composition of the different biomolecules (Table 3), their contribution to the production and remineralization processes can be derived from $J_{\mathrm{O}_{2}}^{\text {bio }}, J_{\mathrm{N}}^{\text {bio }}$ and $J_{\mathrm{P}}^{\text {bio }}$ with the following set of equations:

$$
\begin{array}{r}
\mathrm{C}_{45} \mathrm{H}_{76} \mathrm{O}_{31} \mathrm{~N}_{12} \mathrm{P}_{5}+70.75 \mathrm{O}_{2}+67 \mathrm{OH}^{-} \longrightarrow 45 \mathrm{HCO}_{3}{ }^{-}+12 \mathrm{NO}_{3}{ }^{-}+5 \mathrm{HPO}_{4}{ }^{2-}+46.5 \mathrm{H}_{2} \mathrm{O} \\
\mathrm{C}_{147} \mathrm{H}_{228} \mathrm{O}_{46} \mathrm{~N}_{40} \mathrm{~S}+232.5 \mathrm{O}_{2}+189 \mathrm{OH}^{-} \longrightarrow 147 \mathrm{HCO}_{3}{ }^{-}+40 \mathrm{NO}_{3}{ }^{-}+\mathrm{SO}_{4}{ }^{2-}+135 \mathrm{H}_{2} \mathrm{O} \\
\mathrm{C}_{6} \mathrm{H}_{10} \mathrm{O}_{5}+6 \mathrm{O}_{2}+6 \mathrm{OH}^{-} \longrightarrow 6 \mathrm{HCO}_{3}{ }^{-}+5 \mathrm{H}_{2} \mathrm{O} \\
\mathrm{C}_{53} \mathrm{H}_{89} \mathrm{O}_{6}+72.25 \mathrm{O}_{2}+53 \mathrm{OH}^{-} \longrightarrow 53 \mathrm{HCO}_{3}{ }^{-}+44.5 \mathrm{H}_{2} \mathrm{O}
\end{array}
$$

and the corresponding linear system of mass balance equations:

$$
\begin{aligned}
J_{\mathrm{O}_{2}}^{\text {bio }} & =70.75 J_{\text {Pho }}+232.5 J_{\text {Prot }}+6 J_{\mathrm{Cbh}}+72.25 J_{\text {Lip }} \\
J_{\mathrm{NO}_{3}}^{\text {bio }} & =12 J_{\text {Pho }}+40 J_{\text {Prot }} \\
J_{\mathrm{PO}_{3}}^{\text {bio }} & =5 J_{\text {Pho }}
\end{aligned}
$$



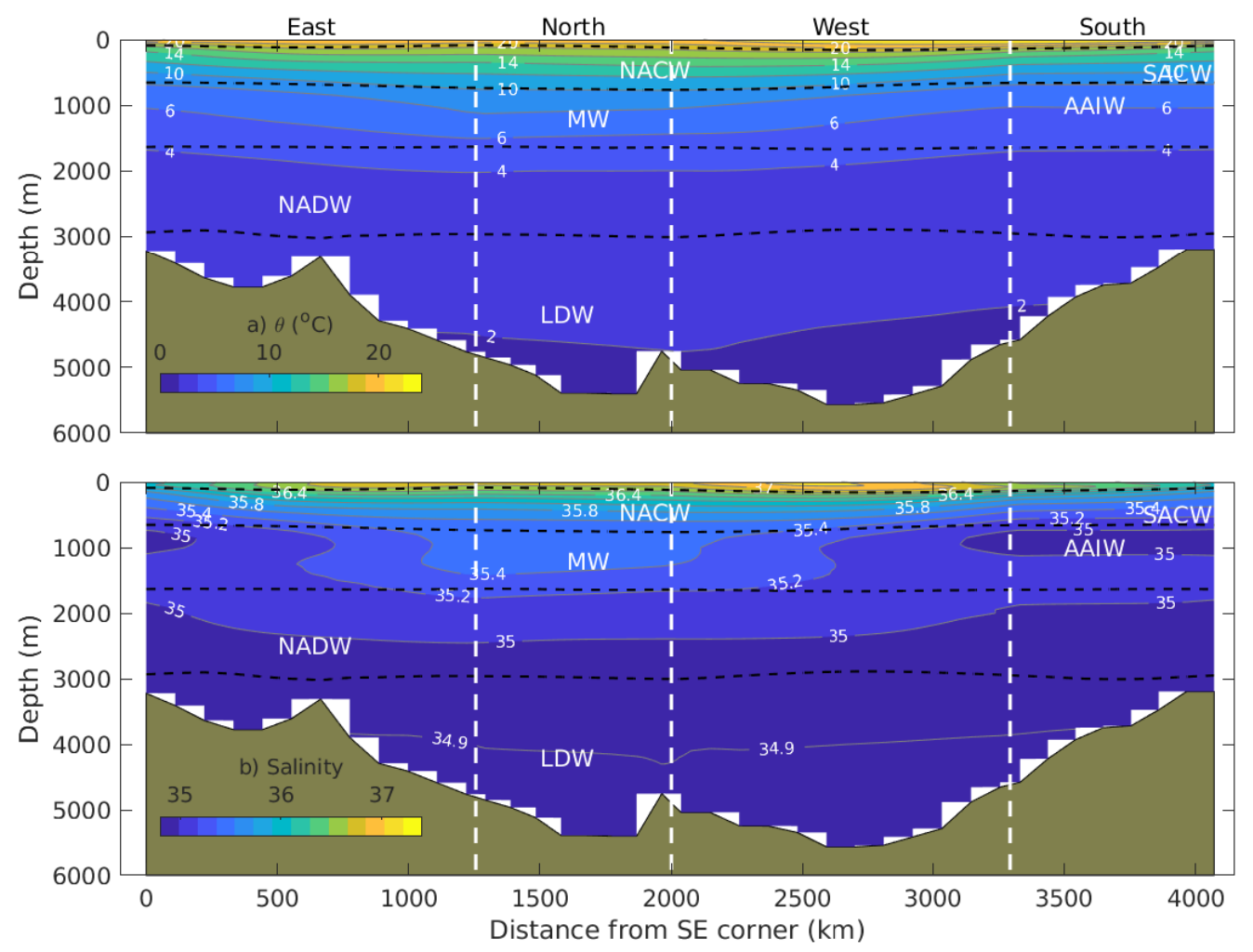

Figure 2: (a) Potential temperature $\left(\theta,{ }^{\circ} \mathrm{C}\right.$ ) and (b) salinity (PSU) distributions along the model box boundaries. The $\mathrm{x}$-axis represents the distance from the southeast corner of the box while moving anti-clockwise along the box boundaries. The horizontal dashed white lines represent the isopycnals delimiting the surface and central waters $\left(\gamma_{n}=26.33 \mathrm{~kg} \mathrm{~m}^{-3}\right)$, the central and intermediate waters $\left(\gamma_{n}=27.38 \mathrm{~kg} \mathrm{~m}^{-3}\right)$ and the intermediate and deep waters $\left(\gamma_{n}=27.99 \mathrm{~kg} \mathrm{~m}^{-3}\right)$, and the deep and bottom waters $\left(\gamma_{n}=28.07 \mathrm{~kg} \mathrm{~m}^{-3}\right)$. The location of the different water masses is indicated: North/South Atlantic Central Water (NACW/SACW), Mediterranean Water (MW), Antarctic Intermediate Water (AAIW), North Atlantic Deep Water (NADW), and Lower Deep Water (LDW).

This is a system of 3 equations and 4 unknowns and has no unique solution. Whereas the contribution of Prt and Pho is determined by $J_{\mathrm{NO}_{3}}^{\text {bio }}$ and $J_{\mathrm{PO}_{4}}^{\text {bio }}$ and equations 18-19, the contributions of Chb and Lip are undetermined. Although the average Cbh/Lip molar ratio is 1.42 (Fraga et al., 1998) in fresh marine phytoplankton, we calculated the range of possible compositions compatible with the production/remineralization of at least $5 \%$ of Chb on weight on one extreme, and at least $5 \%$ Lip on weight on the other extreme. For given $\mathrm{O}_{2}: \mathrm{N}$ and $\mathrm{N}: \mathrm{P}$ molar ratios of the production/remineralization of organic materials, derived from quotients of the respective source terms, the stoichiometric model strongly constrains the possible values for the $\mathrm{C}: \mathrm{N}$ and $\mathrm{O}_{2}: \mathrm{C}$ molar ratios. Taking advantage of that, we estimated the carbon content of the produced/remineralized material and the biogeochemical production rates of dissolved inorganic carbon $\left(J_{\mathrm{DIC}}^{\mathrm{bio}}\right)$. 

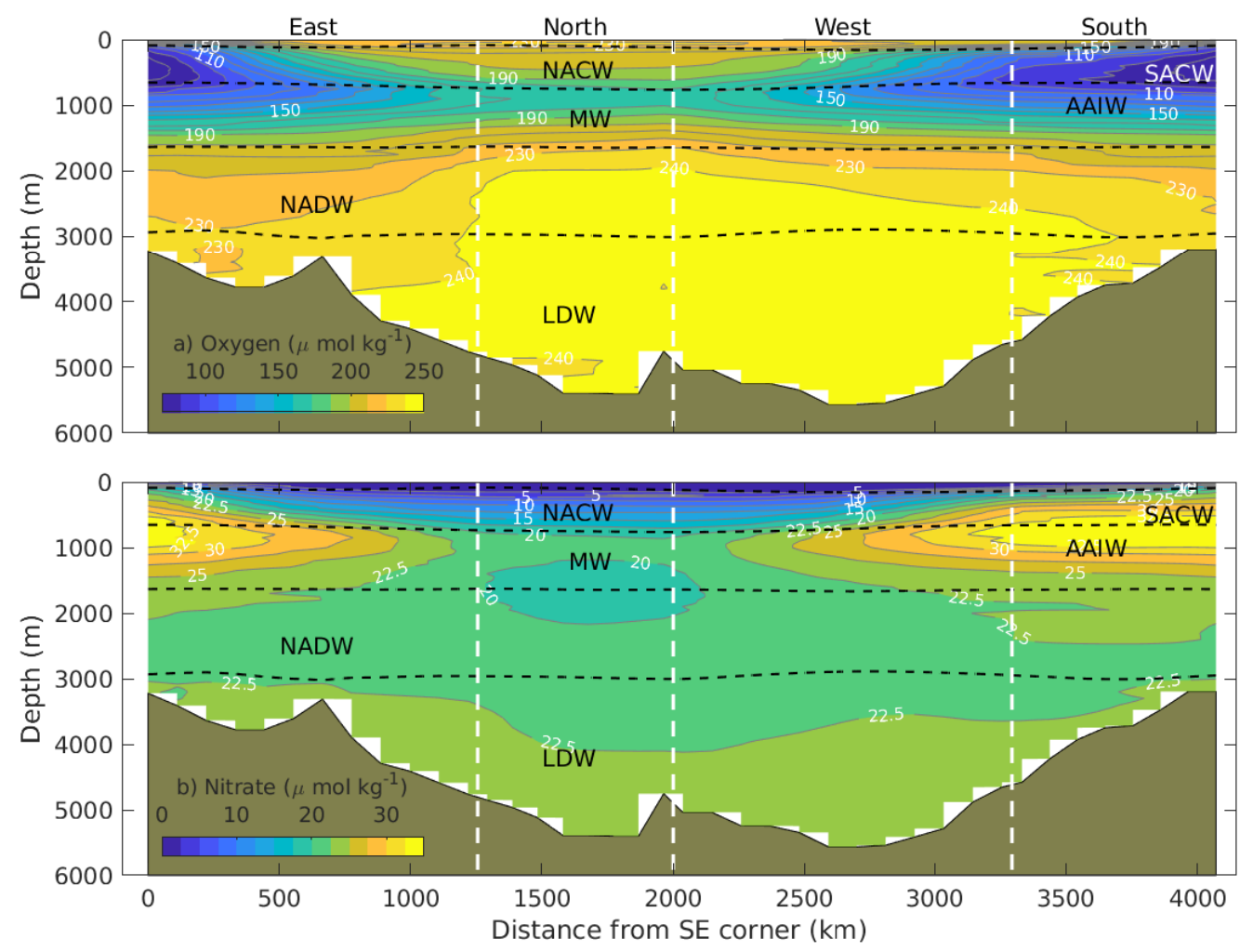

Figure 3: (a) Dissolved oxygen $\left(\mathrm{O}_{2}, \mu \mathrm{mol} \mathrm{kg} \mathrm{k}^{-1}\right)$ and (b) nitrate $\left(\mu \mathrm{mol} \mathrm{kg}{ }^{-1}\right)$ distributions along the model box boundaries. The $\mathrm{x}$-axis represents the distance from the southeast corner of the box while moving anti-clockwise along the box boundaries. The horizontal dashed white lines represent the isopycnals delimiting the surface and central waters $\left(\gamma_{n}=26.33 \mathrm{~kg} \mathrm{~m}^{-3}\right)$, the central and intermediate waters $\left(\gamma_{n}=27.38 \mathrm{~kg} \mathrm{~m}^{-3}\right)$ and the intermediate and deep waters $\left(\gamma_{n}=27.99 \mathrm{~kg} \mathrm{~m}^{-3}\right)$, and the deep and bottom waters $\left(\gamma_{n}=28.07 \mathrm{~kg} \mathrm{~m}^{-3}\right)$. The location of the different water masses is indicated: North/South Atlantic Central Water (NACW/SACW); Mediterranean Water (MW), Antarctic Intermediate Water (AAIW), North Atlantic Deep Water (NADW), and Lower Deep Water (LDW).

\section{Results}

\subsection{Hydrography and water masses}

The climatological distribution of potential temperature and salinity at the surface $\left(\gamma_{n}<26.33 \mathrm{~kg} \mathrm{~m}^{-3}\right.$, $\lesssim 100 \mathrm{~m})$ and thermocline waters $\left(\gamma_{n}<27.38 \mathrm{~kg} \mathrm{~m}^{-3}, \lesssim 700 \mathrm{~m}\right)$ reflects the transition from the warmer (11.0-18.65 $\left.{ }^{\circ} \mathrm{C}\right)$ and saltier $(35.47-36.76)$ NACW to the cooler $\left(9.70-15.25^{\circ} \mathrm{C}\right)$ and fresher $(35.18-35.70)$ SACW to the southeast of the section (Tomczak, 1981, Harvey, 1982), and also the influence of atmospheric heating and evaporation over the subtropical gyre, and coastal upwelling of cool waters to the east of the box (Figure 2). The NACW and SACW dominated the central water levels in the northern and southern sections, while the meridional transects consisted of a mixture of both. The contrast between the North and South Atlantic Central waters can be clearly observed in the dissolved oxygen (Figure 3a) and nitrate distributions (Figure 3b). The SACW, whose purest contribution was observed in the SE corner of the box and decreased to the north and west, was characterized by relatively low oxygen (reaching $\left.\left[\mathrm{O}_{2}\right]<100 \mu \mathrm{mol} \mathrm{kg}{ }^{-1}\right)$ and high nitrate content $\left(\left[\mathrm{NO}_{3}\right] \sim 20-32 \mu \mathrm{mol} \mathrm{kg}{ }^{-1}\right)$, with respect to the 
more ventilated NACW $\left(\left[\mathrm{O}_{2}\right] \sim 190-230 \mu \mathrm{mol} \mathrm{kg}^{-1},\left[\mathrm{NO}_{3}\right] \sim 2-18 \mu \mathrm{mol} \mathrm{kg}^{-1}\right)$ (Tomczak, 1981).

The intermediate levels $\left(27.380<\gamma_{n}<27.922 \mathrm{~kg} \mathrm{~m}^{-3}\right.$, from $\sim 700 \mathrm{~m}$ to $\left.1650 \mathrm{~m}\right)$ were influenced by the confluence of warmer $\left(\sim 11^{\circ} \mathrm{C}\right)$ and saltier $(36.0) \mathrm{MW}$, and the cooler $\left(\sim 7.5^{\circ} \mathrm{C}\right)$ and fresher $(35.0)$ AAIW (Zenk et al., 1991, Arhan et al., 1994, Álvarez et al., 2005). A core of diluted MW was found in the northern limit of the box between 700-1400 m, with salinities $>35.2,\left[\mathrm{O}_{2}\right]>170 \mu \mathrm{mol} \mathrm{\textrm {kg } ^ { - 1 }}$ and $\left[\mathrm{NO}_{3}\right]<20 \mu \mathrm{mol} \mathrm{kg}{ }^{-1}$. The AAIW was dominant in the southeast end with a clear signature of $\mathrm{S}<35.0$ centered at $900-1000 \mathrm{~m}$ (Figure $2 \mathrm{~b}$ ), consistent with its northward propagation along the African continental slope (Iorga and Lozier, 1999, Machín and Pelegrí, 2009, Hernández-Guerra et al., 2017). The AAIW was particularly rich in nutrients $\left(\left[\mathrm{NO}_{3}\right]=27-33 \mu \mathrm{mol} \mathrm{kg}{ }^{-1}\right)$ and poor in oxygen $\left(<170 \mu \mathrm{mol} \mathrm{kg}^{-1}\right)$ (Arhan et al., 1994, Pérez et al., 2001). The deep layers $\left(\gamma_{n}>27.922,>1600 \mathrm{~m}\right)$ were occupied by the different varieties of NADW, with temperatures, salinities, nitrate and oxygen in the range of $2-5^{\circ} \mathrm{C}, 34.9-35.1,19-23 \mu \mathrm{mol} \mathrm{kg}{ }^{-1}, 220-247 \mu \mathrm{mol} \mathrm{kg}^{-1}$, respectively, in line with Pérez et al. (2001) and Hernández-Guerra et al. (2005). The thermohaline signature $\left(\theta \sim 2{ }^{\circ} \mathrm{C}, \mathrm{S} \lesssim 34.9, \gamma_{n}>28.72\right.$ $\mathrm{kg} \mathrm{m}^{-3}$ ) of the LDW was observed in the deeper layers of the northern and western transects, associated with elevated oxygen $\left(\left[\mathrm{O}_{2}\right]>240 \mu \mathrm{mol} \mathrm{kg}{ }^{-1}\right)$ and nitrate $\left(\left[\mathrm{NO}_{3}\right]>22.5 \mu \mathrm{mol} \mathrm{kg}^{-1}\right)$ concentrations.

\subsection{Mass transports and diffusivity}

The net Ekman transport derived from climatological wind data was directed into the box in the eastern $(0.96 \mathrm{~Sv})$ and southern $(0.70 \mathrm{~Sv})$ boundaries, and out of the box in the northern $(-0.07 \mathrm{~Sv})$ and western $(-0.48 \mathrm{~Sv})$ boundaries, resulting in a net convergence of $1.12 \mathrm{~Sv}$ (Figure 4a). The optimized reference velocities at $\gamma_{n}=28.072 \mathrm{~kg} \mathrm{~m}^{-3}$ represented small corrections to the initial assumption of no-motion, and ranged between -0.056 and $0.027 \mathrm{~cm} \mathrm{~s}^{-1}$, lower than the assumed uncertainty $\left( \pm 0.2 \mathrm{~cm} \mathrm{~s}^{-1}\right)$ (Figure $4 b)$.

The absolute geostrophic velocities clearly show the CC flowing at the surface and central water levels (Figure 4c, Figure 5a), entering the box through the northern $(3.20 \pm 0.37 \mathrm{~Sv})$ and eastern $(4.31 \pm 0.43 \mathrm{~Sv})$ boundaries, and turning westward to leave the box mainly through the western boundary $(-6.33 \pm 0.40 \mathrm{~Sv})$ as the NEC, with a weaker flux through the southern boundary $(-1.61 \pm 0.35 \mathrm{~Sv})$. This is in agreement with the classical description of the geostrophic circulation in the Canary basin (Stramma, 1984), and with the range of transports available in literature for the region (Stramma, 1984, Hernández-Guerra et al., 2005, Carracedo et al., 2014, Carracedo Segade et al., 2015) (see Figure 1). A Northeastward recirculation was observed in lower-central upper-intermediate waters (200-1000 m) across the southern limit of the box (0-300 Km and 3100-3600 Km) (Figure 4c). This flow has been described previously to feed the PUC along the NW Africa continental slope (Pelegrí and Peña-Izquierdo, 2015). Otherwise, the mean flow at intermediate and deep waters was weak and following the same direction of the circulation in the upper layers, with a southwestward transport of NADW $(\sim 0.9 \mathrm{~Sv})$. At the deepest layers $\left(\gamma_{n}>28.072 \mathrm{~kg} \mathrm{~m}^{-3},>3000 \mathrm{~m}\right)$, a northeastward cyclonic flow of $\sim 2.0 \mathrm{~Sv}$ could be appreciated through the western and northern boundaries of the box. This transport may be related to the northward flow of LDW described at several locations of the eastern North Atlantic (McCartney et al., 1991, Hernández-Guerra et al., 2005, García-Ibáñez et al., 2015, Ferreira and Kerr, 2017).

The net horizontal mass transport was weak at all neutral layers. A net input of $0.75 \mathrm{~Sv}$ was com- 

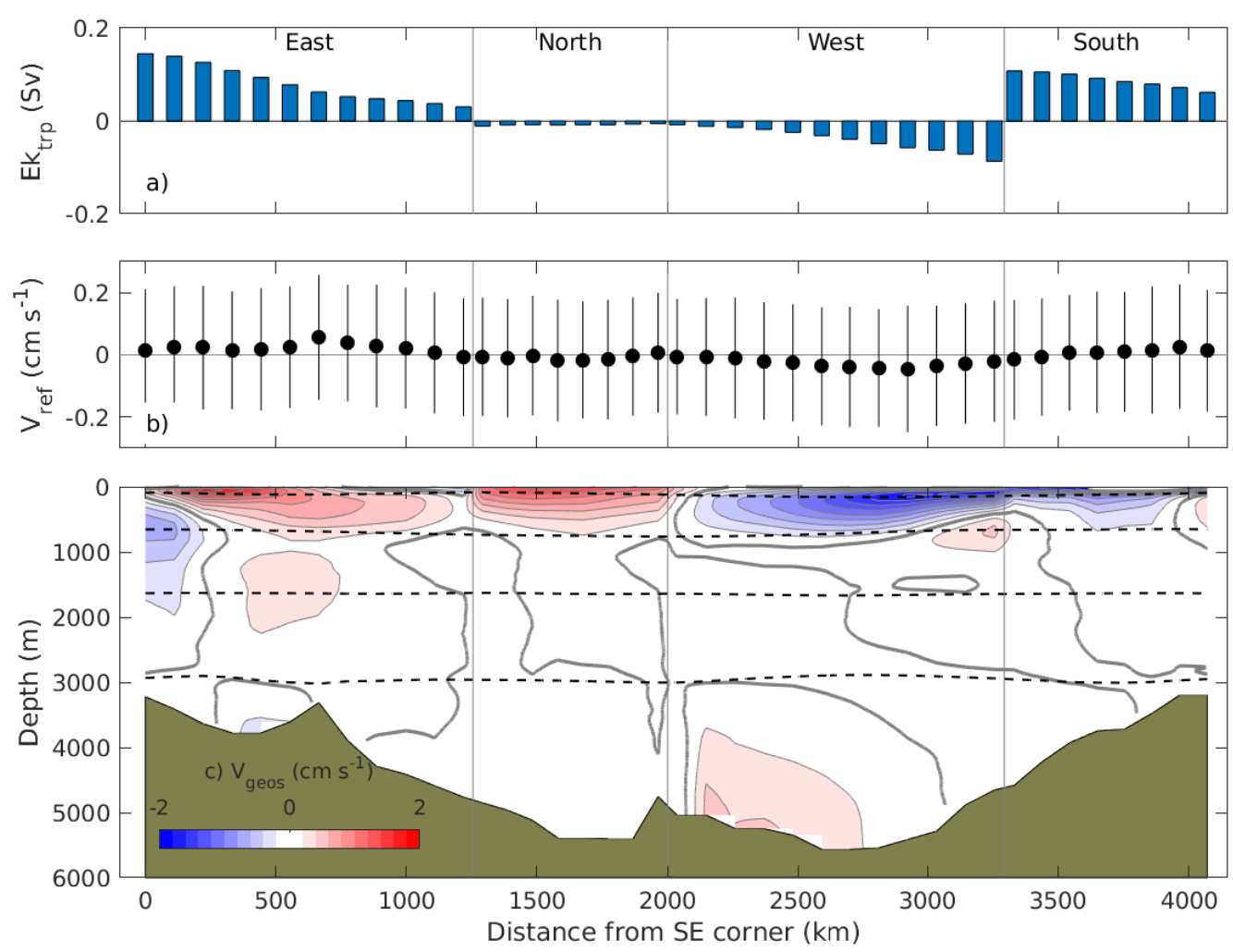

Figure 4: (a) Ekman transport (Sv); (b) optimized reference velocities $\left(V_{\text {ref }}, \mathrm{cm} \mathrm{s}^{-1}\right)$ and errors at $\gamma_{n}=28.07$ $\mathrm{kg} \mathrm{m}^{-3}$, resulting from the solution of the inverse box model; and (c) distribution of the absolute geosgrophic velocities $\left(V_{\text {geos }}, \mathrm{cm} \mathrm{s}^{-1}\right)$ across the model box boundaries. Transports and velocities into (out of) the box are defined positive (negative). The x-axis represents the distance from the southeast corner of the box while moving anti-clockwise along the box boundaries. The horizontal dashed white lines represent the isopycnals delimiting the surface and central waters $\left(\gamma_{n}=26.33 \mathrm{~kg} \mathrm{~m}^{-3}\right)$, the central and intermediate waters $\left(\gamma_{n}=27.38 \mathrm{~kg} \mathrm{~m}^{-3}\right)$ and the intermediate and deep waters $\left(\gamma_{n}=27.99 \mathrm{~kg} \mathrm{~m}^{-3}\right)$, and the deep and bottom waters $\left(\gamma_{n}=28.07 \mathrm{~kg} \mathrm{~m}^{-3}\right)$.

puted for the densest layer, and a net output of $-0.21 \mathrm{~Sv}$ was computed for the surface layer (Figure 5a). In order to compensate for these net transports and ensure mass conservation at each level, upward vertical mass fluxes of 0.24-0.75 Sv were diagnosed for all the neutral interfaces (Figure 5b). The horizontal diffusivity averaged along the box borders, computed with an optimized $\alpha$ factor of $0.09 \pm 0.13$, ranged $43-795 \mathrm{~m}^{2} \mathrm{~s}^{-1}$, with higher values in the surface and central waters (Figure $5 \mathrm{c}$ ). The diagnosed vertical diffusivities ranged between 0.74 and $3.4 \times 10^{-4} \mathrm{~m}^{2} \mathrm{~s}^{-1}$, but they were not significant in deep and bottom waters (Figure 5d).

\subsection{Heat and salt conservation}

The horizontally integrated horizontal advection of heat and salt across the model box boundaries and the net transport due to the horizontal, vertical, advective and diffusive fluxes are shown in Figure 6. In the case of heat, the only relevant horizontal advection fluxes took place at the surface and central waters, with the CC-NEC transporting $519-553 \times 10^{12} \mathrm{~W}$ across the box (Figure 6a). The net horizontal advection resulted in an export (divergence) from the surface layer $\left(-34.2 \pm 5.8 \times 10^{12} \mathrm{~W}\right.$ ), and was very small and not significant for deeper density layers. In terms of the net heat balance at individual 

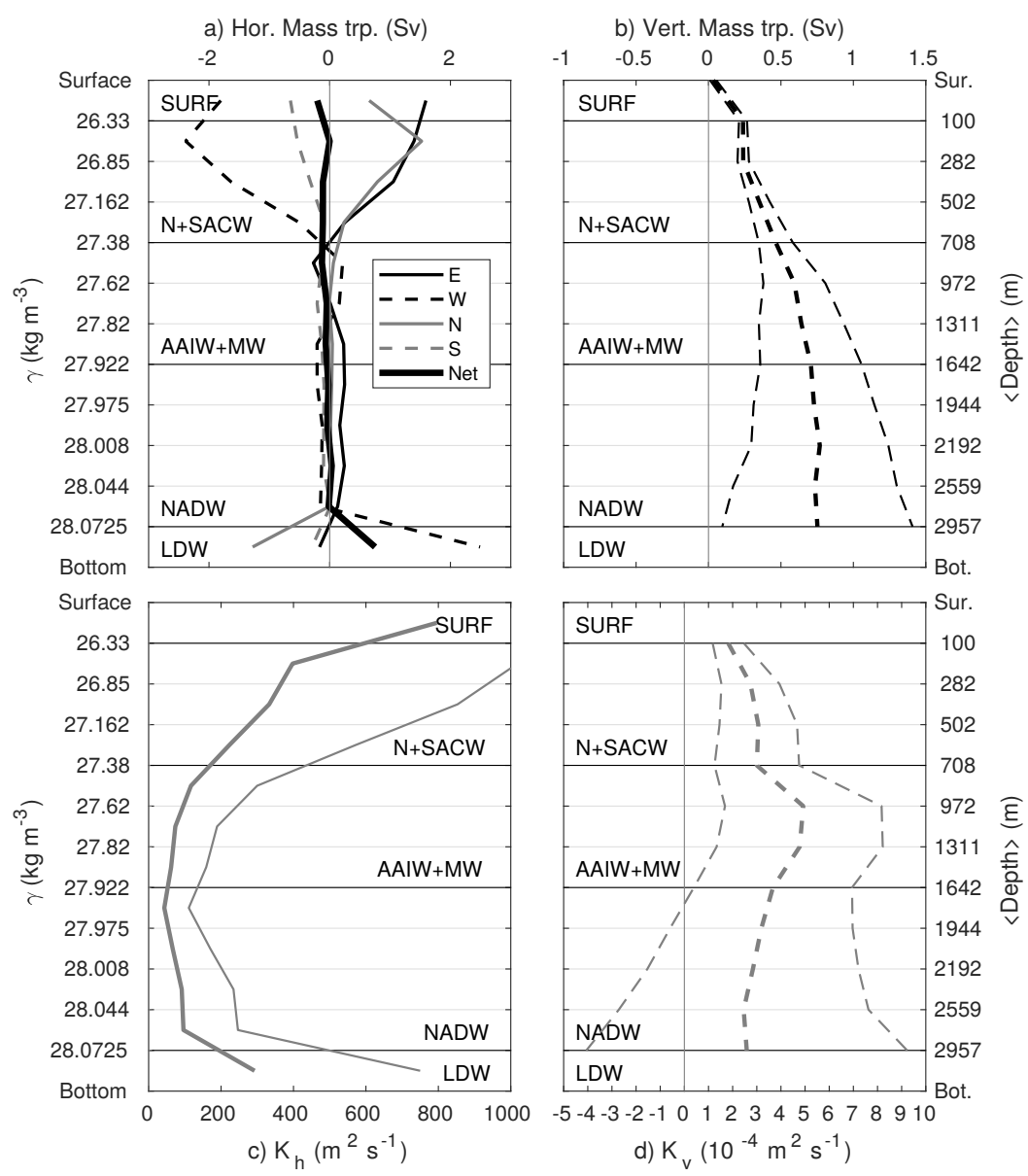

Figure 5: (a) Horizontal advective mass transport ( $\mathrm{Sv}, 1 \mathrm{~Sv}=10^{6} \mathrm{~m}^{3} \mathrm{~s}^{-1}$ ) across the model box boundaries (E, East; W, West; N, North; S, South) and the net accumulated horizontal transport at the center of the density layers; (b) vertical mass transport, (c) horizontal diffusivity averaged along the box borders $\left(K_{\mathrm{h}}, \mathrm{m}^{2} \mathrm{~s}^{-1}\right)$ and (d) vertical diffusivity $\left(K_{\mathrm{v}}, 10^{-4} \mathrm{~m}^{2} \mathrm{~s}^{-1}\right)$. The horizontal black lines represent the isopycnals delimiting the surface and central waters $\left(\gamma_{n}=26.33 \mathrm{~kg} \mathrm{~m}^{-3}\right)$, the central and intermediate waters $\left(\gamma_{n}=27.38 \mathrm{~kg} \mathrm{~m}^{-3}\right)$ and the intermediate and deep waters $\left(\gamma_{n}=27.99 \mathrm{~kg} \mathrm{~m}^{-3}\right)$, and the deep and bottom waters $\left(\gamma_{n}=28.07 \mathrm{~kg} \mathrm{~m}^{-3}\right)$. Water masses: North/South Atlantic Central Water (NACW/SACW); Mediterranean Water (MW), Antarctic Intermediate Water (AAIW), North Atlantic Deep Water (NADW), and Lower Deep Water (LDW). Mean depth of the isopycnal levels are indicated in the right $y$ axis.

density levels, the vertical diffusion compensated the other fluxes such that all the net heat imbalance was concentrated in the surface layer, allowing for compensation by air-sea exchange (Figure 6b).

Aside from heat, the CC-NEC system transported salt across the box at a rate of $280-286 \times 10^{6} \mathrm{~kg} \mathrm{~s}^{-1}$ (Figure 6c). However, unlike for heat, relevant salt transports were also obtained for the deep and bottom layers. Small net horizontal advection was computed for all density levels, but it was only significant in the surface and central waters (Figure 6c,d). Furthermore, these net transports were largely compensated by the net vertical advective transports, and the overall net transport was very small $\left(<0.50 \times 10^{6} \mathrm{~kg} \mathrm{~s}^{-1}\right)$ at all neutral density layers (Figure 6d). Vertical and horizontal diffusion played a minor role in the salt budget. 

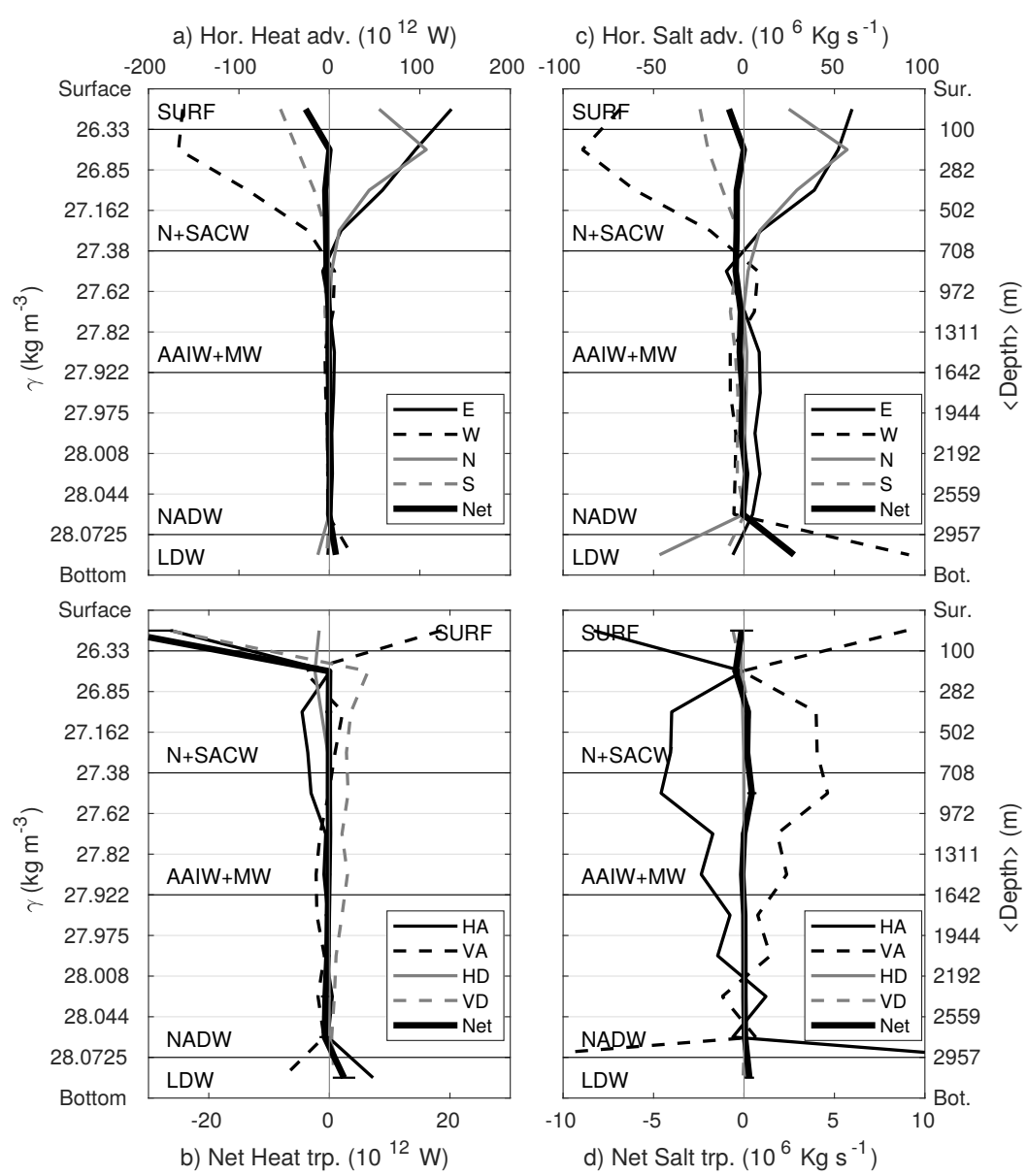

Figure 6: Horizontal advection of (a) heat $\left(10^{12} \mathrm{~W}\right)$ and (c) salt $\left(10^{6}, \mathrm{~kg} \mathrm{~s}^{1}\right)$ across the model box boundaries (E, East; W, West; N, North; S, South) and the net accumulated horizontal advection at the center of the neutral density layers. (b) Heat and (d) salt net horizontal (HA) and vertical advection (VA), horizontal (HD) and vertical diffusion (VD), and net transport at the center of the neutral density layers (positive into the box). Error bars for the net transport term are shown as horizontal lines. Water masses: North/South Atlantic Central Water (NACW/SACW); Mediterranean Water (MW), Antarctic Intermediate Water (AAIW), North Atlantic Deep Water (NADW), and Lower Deep Water (LDW). Mean depth of the isopycnal levels are indicated in the right y axis.

\subsection{Oxygen and nutrient transports}

In the case of oxygen, the CC-NEC transported $1444-1534 \mathrm{kmol} \mathrm{O}_{2} \mathrm{~s}^{-1}$ across the box (Figure 7a). Horizontal advection was weak and not-significant $\left(<80 \mathrm{kmol} \mathrm{O}_{2} \mathrm{~s}^{-1}\right)$ at intermediate layers and it was larger but not-significant in deep waters $\left(\sim 200 \mathrm{kmol} \mathrm{O}_{2} \mathrm{~s}^{-1}\right.$, westward). In the bottom layer, the LDW transported $433-625 \mathrm{kmol} \mathrm{O}_{2} \mathrm{~s}^{-1}$ from the west to the north face of the box (Figure 7a). The net horizontal advection was positive (convergence) in the central waters $\left(90 \pm 30 \mathrm{kmol} \mathrm{O}_{2} \mathrm{~s}^{-1}\right)$ (Figure $7 \mathrm{~b}$ ), due to the larger oxygen concentration in the inflowing compared to the outflowing waters, and in the bottom layer $\left(192 \pm 167 \mathrm{kmol} \mathrm{O}_{2} \mathrm{~s}^{-1}\right)$, due to the convergence of the horizontal advection of mass (Figure 5a). Net horizontal diffusion was weaker and negative (divergence) at a rate of $-31 \pm 48 \mathrm{kmol} \mathrm{O}_{2} \mathrm{~s}^{-1}$ in the surface and central waters (Figure 7b), due mainly to the down-gradient flux across the East and South borders (not shown). The vertical fluxes redistributed the net oxygen input in the the central $\left(141 \pm 46 \mathrm{kmol} \mathrm{O}_{2} \mathrm{~s}^{-1}\right)$ and intermediate layers $\left(99 \pm 56 \mathrm{kmol} \mathrm{O}_{2} \mathrm{~s}^{-1}\right)$, while not-significant net negative 
a) Hor. $\mathrm{O}_{2}$ adv. $\left(\mathrm{kmol} \mathrm{O}_{2} \mathrm{~s}^{-1}\right)$

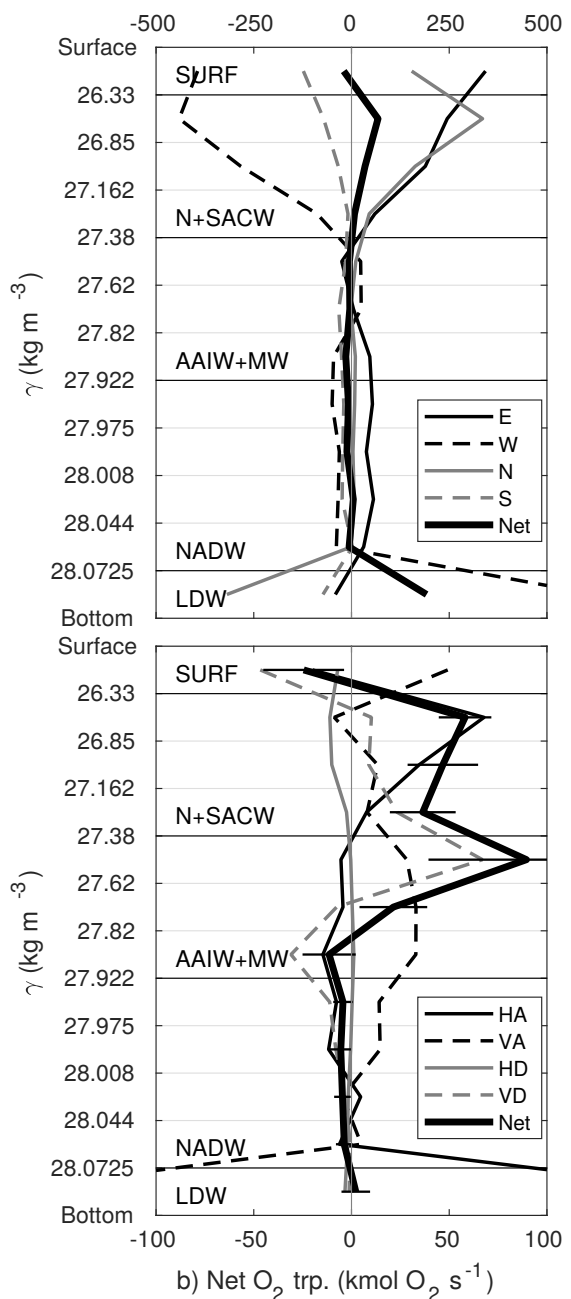

c) Hor. $\mathrm{NO}_{3}$ adv. (kmol N s${ }^{-1}$ )
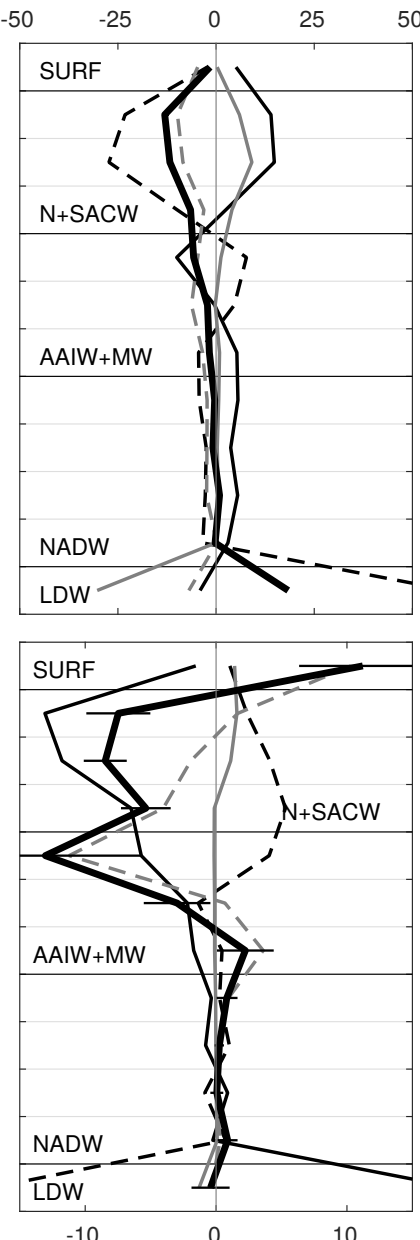

d) $\mathrm{Net} \mathrm{NO}_{3}$ trp. $\left(\mathrm{kmol} \mathrm{N} \mathrm{s}^{-1}\right)$ e) Hor. $\mathrm{PO}_{4}$ adv. (kmol P s${ }^{-1}$ )

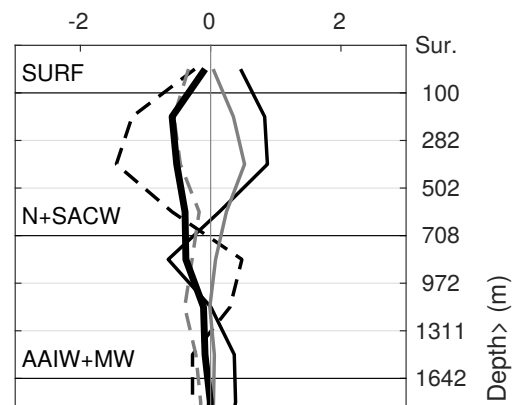

छ
$\hat{\frac{1}{亠}}$
$\frac{0}{0}$

Figure 7: Horizontal advection of (a) oxygen $\left(\mathrm{kmol} \mathrm{O}_{2} \mathrm{~s}^{-1}\right)$, (c) nitrate $\left(\mathrm{kmol} \mathrm{N} \mathrm{s}^{-1}\right)$ and (e) phosphate (kmol N $\mathrm{s}^{-1}$ ) across the model box boundaries (E, East; W, West; N, North; S, South) and the net accumulated horizontal advection at the center of the neutral density layers. (b) Oxygen, (c) nitrate and (d) phosphate net horizontal (HA) and vertical advection (VA), horizontal (HD) and vertical diffusion (VD) and net transport at the center of the neutral density layers (positive into the box). Error bars for the net transport term are shown as horizontal lines. Water masses: North/South Atlantic Central Water (NACW/SACW); Mediterranean Water (MW), Antarctic Intermediate Water (AAIW), North Atlantic Deep Water (NADW), and Lower Deep Water (LDW). Mean depth of the isopycnal levels are indicated in the right y axis.

fluxes were computed for the deep plus bottom $\left(-17 \pm 19 \mathrm{kmol} \mathrm{O}_{2} \mathrm{~s}^{-1}\right)$, and surface layer $(-24 \pm 21$ $\left.\mathrm{kmolO}_{2} \mathrm{~s}^{-1}\right) 7 \mathrm{~b}$ ).

Nitrate and phosphate exhibited similar transport patterns (Figure 7c-f). The CC-NEC system transported $56-89 \mathrm{kmol} \mathrm{N} \mathrm{s}^{-1}\left(3.4-5.0 \mathrm{kmol} \mathrm{P} \mathrm{s}^{-1}\right)$ of nitrate (phosphate), while the NADW and the LDW transported $\sim 20 \mathrm{kmol} \mathrm{N} \mathrm{s}^{-1}\left(\sim 1.3 \mathrm{kmol} \mathrm{P} \mathrm{s}^{-1}\right)$ and $41-60 \mathrm{kmol} \mathrm{N} \mathrm{s}^{-1}\left(2.8-4.0 \mathrm{kmol} \mathrm{P} \mathrm{s}^{-1}\right)$ (Figure $7 \mathrm{c}, \mathrm{e})$. The net horizontal advection was divergent for both tracers $\left(-32.9 \pm 6.5 \mathrm{kmol} \mathrm{N} \mathrm{s}^{-1}\right.$ and $\left.-1.59 \pm 0.40 \mathrm{kmol} \mathrm{P} \mathrm{s}^{-1}\right)$ in the surface and central waters, due to the southwestward increase of nutrient concentrations; and convergent in the bottom layer (Figure 7d,f), due to net mass convergence. On the other hand, horizontal diffusion was convergent but not-significant for both nutrients in the surface and 


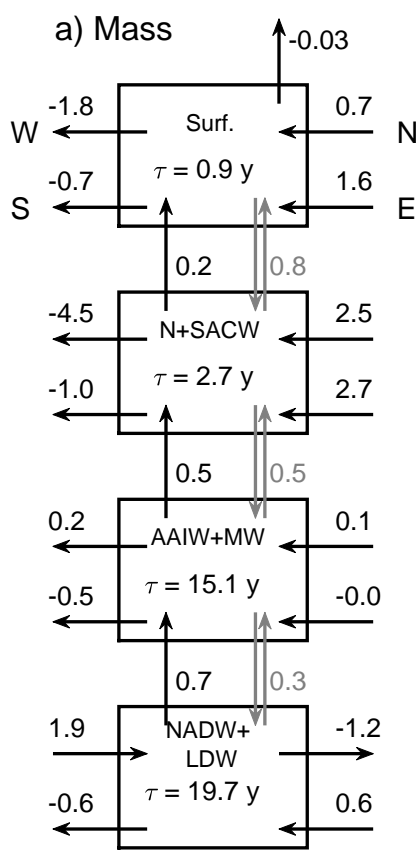

(Sv)

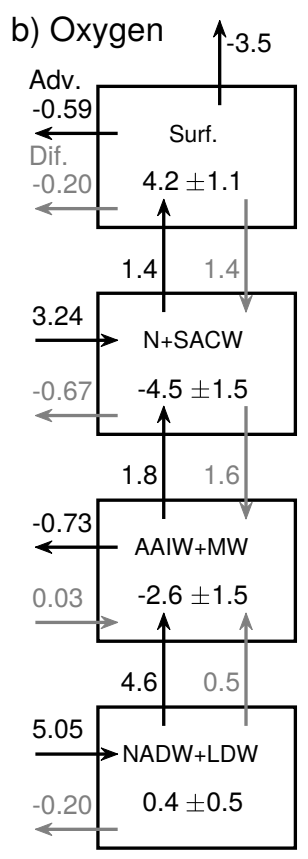

$\left(\mathrm{molO} \mathrm{O}^{-2} \mathrm{yr}^{-1}\right)$

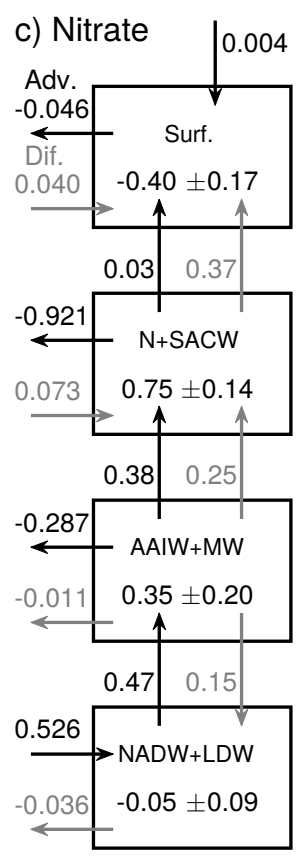

$\left(\mathrm{mol} \mathrm{N} \mathrm{m} \mathrm{m}^{-2} \mathrm{yr}^{-1}\right)$

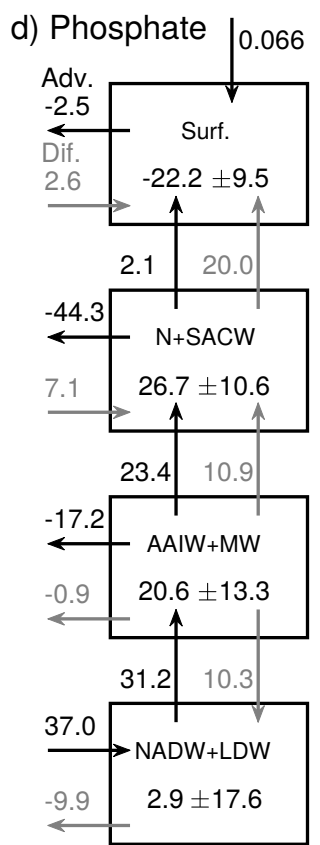

$\left(\mathrm{mmol} \mathrm{P} \mathrm{m} \mathrm{m}^{-2} \mathrm{yr}^{-1}\right)$

Figure 8: Transports and budgets of (a) mass, (b) oxygen, (c) nitrate and (d) phosphate for the main water masses present in the model box. Black and gray arrows represent advective and diffusive fluxes, respectively. Horizontal arrows represent the advective mass transport across the box borders in panel (a) and the net advective (black) and diffusive (gray) tracer transport into/out of the box in panels (b-d). Horizontal diffusion is not shown in panel (a). The vertical black arrows in the upper border of the surface box represent the exchange with the atmosphere. Inside the boxes of (a), renewal times are presented, $\tau=V / \sum T^{+}$, where $V=\Delta d \cdot A^{S}$ is the approximate box volume and $\sum T^{+}$is the sum of all the positive advective fluxes into the box plus the diffusive exchange. Inside the boxes of $(\mathrm{b}-\mathrm{d})$, the biogeochemical sources-minus-sinks $\left(J_{C}\right)$ terms are represented. Oxygen and nutrient fluxes have been normalized by the box surface area $\left(A^{S}\right)$ and are reported in $\mathrm{mol} \mathrm{O}_{2} \mathrm{~m}^{-2} \mathrm{yr}^{-1}$, mol N m${ }^{-2} \mathrm{yr}^{-1}$ (nitrate) and mmol $\mathrm{P} \mathrm{m}^{-2} \mathrm{yr}^{-1}$ (phosphate). Oxygen air-sea exchange flux was computed using the parameterizations in Table 2, while atmospheric deposition fluxes of nitrate and phosphate are from Jickells et al. (2017) and Mahowald et al. (2008), respectively. Water masses: North/South Atlantic Central Water (NACW/SACW); Mediterranean Water (MW), Antarctic Intermediate Water (AAIW), North Atlantic Deep Water (NADW), and Lower Deep Water (LDW).

central waters layers $\left(4.0 \pm 6.2 \mathrm{kmol} \mathrm{N} \mathrm{s}^{-1}\right.$ and $\left.0.34 \pm 0.53 \mathrm{kmol} \mathrm{P} \mathrm{s}^{-1}\right)$, due to the down-gradient flux across the East and South borders. After considering the vertical fluxes, net convergence was found in the surface layer $\left(11.2 \pm 4.9 \mathrm{kmol} \mathrm{N} \mathrm{s}^{-1}\right.$ and $\left.0.55 \pm 0.26 \mathrm{kmol} \mathrm{P} \mathrm{s}^{-1}\right)$ and net divergence in the central $\left(-21.3 \pm 4.5 \mathrm{kmol} \mathrm{N} \mathrm{s}^{-1}\right.$ and $\left.-0.56 \pm 0.36 \mathrm{kmol} \mathrm{P} \mathrm{s}^{-1}\right)$ and intermediate waters $\left(-13.8 \pm 7.7 \mathrm{kmol} \mathrm{N} \mathrm{s}^{-1}\right.$ and $-0.83 \pm 0.50 \mathrm{kmol} \mathrm{P} \mathrm{s}^{-1}$ ). Net fluxes were not significant in the deep and bottom layers.

\subsection{Epipelagic net production: rates and stoichiometry}

Net production/consumption rates of dissolved oxygen and inorganic nutrients in the main water masses of the study area are investigated in this section and presented in Figure 8, together with a summary of the mass, oxygen and nutrient transports described in section 3.4 and box renewal times $(\tau)$. The surface waters box $(\lesssim 100 \mathrm{~m})$ presented a renewal time of 0.9 years and a net import of nitrate $(0.40 \pm 0.17 \mathrm{~mol} \mathrm{~N}$ $\left.\mathrm{m}^{-2} \mathrm{y}^{-1}\right)$ and phosphate $\left(22.2 \pm 9.5 \mathrm{mmol} \mathrm{P} \mathrm{m}^{-2} \mathrm{y}^{-1}\right)$ (Figure 8). Atmospheric deposition fluxes of nitrate 
Table 4: Molar ratios of the organic matter produced in the surface layer and remineralized in the central waters $(\mathrm{CW})$ and central waters + intermediate waters + deep waters $(\mathrm{CW}+\mathrm{IW}+\mathrm{DW})$ layers. The $\mathrm{O}_{2}: \mathrm{N}$ and $\mathrm{N}: \mathrm{P}$ molar ratios were derived directly from the nutrient budgets and the $\mathrm{O}_{2}: \mathrm{C}$ and $\mathrm{C}: \mathrm{N}$ were calculated using the Fraga et al. (1998) stoichiometric model. The ranges shown in squared brackets: ${ }^{*}$ ) represent the $90 \%$ confidence intervals, $(* *)$ emcompass the results obtained with the different parameterizations of the atmospheric flux (Table $2)$, and $(* * *)$ correspond to the limit cases where $\mathrm{Cbh} / \mathrm{Lip}=0.05$ (5\% carbohydrates on weight) and $\mathrm{Cbh} / \mathrm{Lip}=$ 19 (5\% lipids). The rates of biogeochemical production of dissolved inorganic carbon $\left(J_{\mathrm{DIC}}\right)$, calculated from the nitrate production rates (Figure 8) and the C:N molar ratio, are also shown. Rates of production/degradation of Phosphorus compounds (Phos), Proteins (Prot) and Carbohydrates plus Lipids (Cbh\&Lip) are also reported, with their relative contribution (percentage in weight) in brackets.

\begin{tabular}{llll}
\hline & Surface & $\mathrm{CW}$ & $\mathrm{CW}+\mathrm{IW}+\mathrm{DW}$ \\
\hline$-\mathrm{O}_{2}: \mathrm{N}$ & $10.5[6.8-18.9]^{* *}$ & $6.0[4.5-7.3]^{*}$ & $6.3[3.4-8.2]^{*}$ \\
$\mathrm{~N}: \mathrm{P}$ & $18.1[17.5-19.4]^{*}$ & $28[22-41]^{*}$ & $21[17-30]^{*}$ \\
$-\mathrm{O}_{2}: \mathrm{C}$ & $1.39[1.28-1.47]^{* * *}$ & $1.568[1.560-1.574]^{* * *}$ & $1.55[1.53-1.56]^{* * *}$ \\
$\mathrm{C}: \mathrm{N}$ & $7.6[7.1-8.2]^{* * *}$ & $3.80[3.79-3.83]^{* * *}$ & $4.06[4.02-4.13]^{* * *}$ \\
$-\mathrm{O}_{2}: \mathrm{C}: \mathrm{N}: \mathrm{P}$ & $190: 137: 18: 1$ & $168: 107: 28: 1$ & $132: 85: 21: 1$ \\
\hline$J_{\text {DIC }}\left(\mathrm{mol} \mathrm{C} \mathrm{m}^{-2} \mathrm{yr}^{-1}\right)$ & $-3.1 \pm 1.3$ & $2.9 \pm 0.5$ & $4.3 \pm 1.4$ \\
\hline$J_{\text {Phos }}\left(\mathrm{g} \mathrm{m}^{-2} \mathrm{yr}^{-1}\right)$ & $6.4(9 \%)$ & $-7.6(12 \%)$ & $-14.4(14 \%)$ \\
$J_{\text {Prot }}\left(\mathrm{g} \mathrm{m}^{-2} \mathrm{yr}^{-1}\right)$ & $29.0(43 \%)$ & $-57.1(86 \%)$ & $-77.8(77 \%)$ \\
$J_{\text {Cbh\&Lip }\left(\mathrm{g} \mathrm{m}^{-2} \mathrm{yr}^{-1}\right)} 32.4(48 \%)$ & $-1.9(3 \%)$ & $-8.3(8 \%)$ \\
\hline
\end{tabular}

$\left(0.0043 \mathrm{~mol} \mathrm{~N} \mathrm{~m}^{-2} \mathrm{yr}^{-1}\right)$ and phosphate $\left(0.066 \mathrm{mmol} \mathrm{P} \mathrm{m}^{-2} \mathrm{yr}^{-1}\right)$ were several orders of magnitude lower than the net convergence of the ocean transports, and they did not influence the net budgets. In the case of oxygen, the advective and diffusive fluxes resulted in a net export of $-0.72 \pm 0.60 \mathrm{~mol} \mathrm{O}_{2} \mathrm{~m}^{-2} \mathrm{yr}^{-1}$. Furthermore, we added an outward flux to the atmosphere of $-3.47 \pm 0.90 \mathrm{~mol} \mathrm{O}_{2} \mathrm{~m}^{-2} \mathrm{yr}^{-1}$. A relatively small part of the air-sea oxygen flux $\left(-0.97 \pm 0.26 \mathrm{~mol} \mathrm{O}_{2} \mathrm{~m}^{-2} \mathrm{yr}^{-1}\right)$ was driven by the thermal exchange (Eq. 12), and the larger part was driven by net biological production. Overall, an export (import) of oxygen (nitrate, phosphate) was computed for the surface box, that we assumed to be compensated by a biological net production of $4.2 \pm 1.1 \mathrm{~mol} \mathrm{O}_{2} \mathrm{~m}^{-2} \mathrm{yr}^{-1}$ and a consumption of $-0.40 \pm 0.17 \mathrm{~mol} \mathrm{~N} \mathrm{~m}^{-2} \mathrm{yr}^{-1}$ of nitrate and $-22.2 \pm 9.5 \mathrm{mmol} \mathrm{P} \mathrm{m}^{-2} \mathrm{yr}^{-1}$ of phosphate, in order to keep the steady state condition.

A N:P molar ratio of 18.1 was computed for the net community production (NCP) in the surface layer (Table 4), while the $-\mathrm{O}_{2}: \mathrm{N}$ ratio was 10.5 , being both slighly larger than the Redfield proportions of 16 and -9.33 (Anderson, 1995). However, due to the relatively large uncertainty of air-sea oxygen fluxes, the deviation from the Redfield proportion was only significant for the N:P ratio. With the stoichiometric model proposed by Fraga et al. (1998), we obtained that the organic matter produced was composed by $48 \%$ in weight of carbohydrates and lipids, $43 \%$ of proteins and $9 \%$ of phosphorus compounds. Hence, it was slightly poor in proteins and phosphorus compounds with respect to the Redfieldian organic matter, composed by $47 \%$ and $12 \%$ in weight of proteins and phosphorus compounds, respectively (Table 3 ). The $-\mathrm{O}_{2}: \mathrm{C}$ and $\mathrm{C}: \mathrm{N}$ ratios derived from the stoichiometric model were 1.39 and 7.6, respectively. With this, the $-\mathrm{O}_{2}: \mathrm{C}: \mathrm{N}: \mathrm{P}$ ratios of organic matter production would be 190:137:18:1, higher than Redfield but identical to the average composition of particulate organic matter in upwelling-influenced systems (Martiny et al., 2013). Using the computed C:N ratio and the nitrate consumption rate, we estimated a net uptake of dissolved inorganic carbon (DIC) of $-3.1 \pm 1.3 \mathrm{~mol} \mathrm{C} \mathrm{m}^{-2} \mathrm{yr}^{-1}$. 

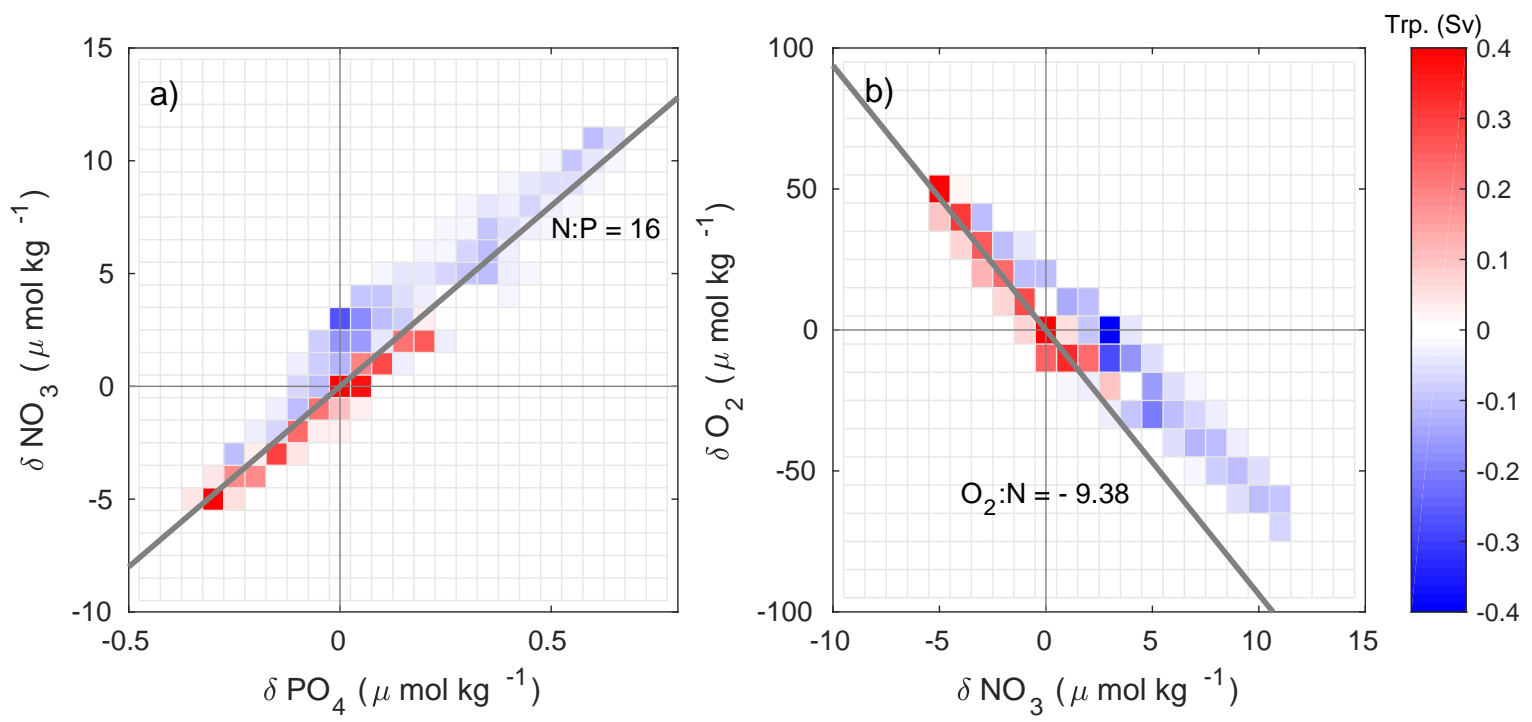

Figure 9: Mass transports (Sv) at the central waters accumulated in bins of concentration anomalies of (a) nitrate $\left(\mathrm{NO}_{3}\right)$ and phosphate $\left(\mathrm{PO}_{4}\right)$, and $(\mathrm{b})$ oxygen $\left(\mathrm{O}_{2}\right)$ and nitrate $\left(\mathrm{NO}_{3}\right)$. Concentration anomalies were calculated as the residuals of a multilinear fit against potential temperature and salinity $(\delta C=C-a \theta-b S-c$ ), in order to rule out the effect of water mass mixing. Thick gray lines represent Redfieldian molar ratios. Red (blue) colors represent transports into (out of) the box.

\subsection{Mesopelagic and deep net remineralization: rates and stoichiometry}

The central waters $(100-700 \mathrm{~m})$ inside the box were characterized by a renewal time of 2.7 years, a net biogeochemical consumption of oxygen $\left(-4.5 \pm 1.5 \mathrm{~mol} \mathrm{O}_{2} \mathrm{~m}^{-2} \mathrm{yr}^{-1}\right)$ and a net production of nitrate $\left(0.75 \pm 0.14 \mathrm{~mol} \mathrm{~N} \mathrm{~m}^{-2} \mathrm{yr}^{-1}\right)$ and phosphate $\left(26.7 \pm 10.6 \mathrm{mmol} \mathrm{P} \mathrm{m}^{-2} \mathrm{yr}^{-1}\right)$, indicative of degradation of organic matter in the twilight zone (Figure 8). The diagnosed remineralization rates were due to the net supply (removal) of oxygen (nitrate, phosphate) by the CC-NEC currents, with little contribution from vertical and diffusive fluxes (Figure 8). The net advective fluxes were caused by the southwestwards downstream decrease (increase) of oxygen (nutrients) concentration, suggesting that organic materials produced closer to the coast could be remineralized in the course of their offshore transport.

In order to rule out the possible effect that the mixing between the NACW and SACW could have in these budgets, we computed the oxygen and nutrient concentration anomalies $\delta C$ with respect to a multilinear fit against potential temperature and salinity, i.e. $\delta C=C-a \theta-b S-c$, where $a, b$ and $c$ were the fitting parameters. Then, the mass transports in central waters were accumulated in bins of concentration anomalies (Figure 9). The waters entering the box were characterized mostly by negative (positive) anomalies of nutrients (oxygen), while the waters leaving the box presented mostly positive (negative) anomalies of nutrients (oxygen). This fact confirms that the diagnosed imbalances were due to biogeochemical transformations (remineralization) and not to uncompensated mixing of the different water masses. Furthermore, the outflowing waters presented an enrichment in nitrate with respect to oxygen and phosphorus, relative to the Redfield proportions, indicating that the remineralization processes took place at relatively low $-\mathrm{O}_{2}: \mathrm{N}(=6)$ and high $\mathrm{N}: \mathrm{P}(=28)$ ratios (Figure 9 and Table 4).

Net remineralization was also computed for the intermediate layers $(700-1650 \mathrm{~m})$ at rates of $-2.6 \pm$ $1.5 \mathrm{~mol} \mathrm{O}_{2} \mathrm{~m}^{-2} \mathrm{yr}^{-1}$ for oxygen, $0.35 \pm 0.20 \mathrm{~mol} \mathrm{~N} \mathrm{~m}^{-2} \mathrm{yr}^{-1}$ for nitrate and $20.6 \pm 13.3 \mathrm{mmol} \mathrm{P} \mathrm{m}^{-2} \mathrm{yr}^{-1}$ 
for phosphate, weaker compared to central waters. Overall, when integrated from $\gamma_{n}=26.33 \mathrm{~kg} \mathrm{~m}^{-3}$ $(\sim 100 \mathrm{~m})$ to the bottom, significant rates of net oxygen consumption $\left(6.7 \pm 3.3 \mathrm{~mol} \mathrm{O}_{2} \mathrm{~m}^{-2} \mathrm{yr}^{-1}\right)$ and nitrate $\left(1.05 \pm 0.35 \mathrm{~mol} \mathrm{~N} \mathrm{~m}^{-2} \mathrm{yr}^{-1}\right)$ and phosphate $\left(50 \pm 21 \mathrm{mmol} \mathrm{P} \mathrm{m}^{-2} \mathrm{yr}^{-1}\right)$ production were obtained.

The molar ratios of remineralization in mesopelagic and bathypelagic waters $(\mathrm{CW}+\mathrm{IW}+\mathrm{DW}) \mathrm{com}-$ puted from the nutrient budgets were $-\mathrm{O}_{2}: \mathrm{N}=6.3$ and $\mathrm{N}: \mathrm{P}=21$, respectively (Table 4), showing a marked deviation from the Redfield stoichiometry with a strong preferential nitrogen remineralization. This anomaly derives mainly from the stoichimetry of respiration in central waters $\left(-\mathrm{O}_{2}: \mathrm{N}=6.0\right.$ and $\mathrm{N}: \mathrm{P}=28$ ) (Table 4). The stoichiometric model proposed by Fraga et al. (1998) revealed an enhanced consumption of proteins $(77 \%)$ and a reduced consumption of carbohydrates and lipids (8\%) (Table 4 ), with respect to the average phytoplankton composition (47\% and 40\%, respectively, Table 3) and also the averaged stoichiometry of deep waters $(>400 \mathrm{~m})$ remineralization (170:117:16:1) computed by Anderson and Sarmiento (1994). As a consequence, the $-\mathrm{O}_{2}: \mathrm{C}$ and $\mathrm{C}: \mathrm{N}$ ratios determined using the stoichiometric model were 1.55 and 4.04, respectively. Altogether, the averaged elemental proportions of the degraded materials would be $-\mathrm{O}_{2}: \mathrm{C}: \mathrm{N}: \mathrm{P} \sim 145: 94: 23: 1$. The derived C:N proportions of respiration imply a net production of DIC of $4.3 \pm 1.4 \mathrm{~mol} \mathrm{C} \mathrm{m}^{-2} \mathrm{yr}^{-1}$ over the whole aphotic ocean, of which $2.9 \pm 0.5 \mathrm{~mol} \mathrm{C} \mathrm{m}^{-2} \mathrm{yr}^{-1}$ correspond to the central waters.

\section{Discussion}

\subsection{Biogeochemical rates and metabolic balance}

Our results point to a net autotrophic metabolic balance (positive NCP) of the surface ocean $(<100 \mathrm{~m})$ in the study region, with net production rates of $4.2 \pm 1.1 \mathrm{~mol} \mathrm{O}_{2} \mathrm{~m}^{-2} \mathrm{yr}^{-1}$ and $3.1 \pm 1.3 \mathrm{~mol} \mathrm{C} \mathrm{m}^{-2} \mathrm{yr}^{-1}$ of oxygen and organic carbon, respectively; not supporting the results from in vitro oxygen incubations in the same area (Duarte et al., 2001, del Giorgio and Duarte, 2002, Duarte et al., 2013, Serret et al., 2015). The supply of carbon from more productive regions has been invoked to justify the negative NCP obtained by that method (Duarte et al., 2013). Our results indicate that, although our study was carried out over an area of presumably significant influence of allochthonous carbon inputs, they do not shift the metabolic state of the upper-ocean ecosystem towards net heterotrophy, at least in the time scales associated with the renewal time of the surface layer of the box ( $\sim 1$ year). On the other hand, our results are in good agreement with biogeochemical estimates and ecosystem models, arguing for the prevalence of net autotrophy (González-Dávila et al., 2007, Fernández-Castro et al., 2012, Emerson, 2014, Letscher and Moore, 2017, Lovecchio et al., 2017). Very recently, Letscher and Moore (2017) evaluated the metabolic state of the oligotrophic ocean at a global scale using a 3D ecosystem model. They reported an areal rate of $\mathrm{O}_{2} \mathrm{NCP}$ of $1.46 \pm 0.59 \mathrm{~mol}^{\circ} \mathrm{O}_{2} \mathrm{~m}^{-2} \mathrm{y}^{-1}$ for the subtropical North Atlantic, but with a tendency to higher values in the eastern basin, in good agreement with our estimates. More locally, Lovecchio et al. (2017) investigated the effect of the long-range carbon export from the CanUS using a mesoscale-resolving circulation model coupled to an ecosystem model, and found net autotrophy in the epipelagic waters of the adjacent subtropical gyre at rates roughly consistent with our values.

On the other hand, our rates of remineralization in mesopegalic and bathypelagic waters $(6.7 \pm 3.3$ $\mathrm{mol} \mathrm{O}_{2} \mathrm{~m}^{-2} \mathrm{yr}^{-1}$ and $4.3 \pm 1.4 \mathrm{~mol} \mathrm{C} \mathrm{m}^{-2} \mathrm{yr}^{-1}$ ) are in good agreement with the oxygen consumption 


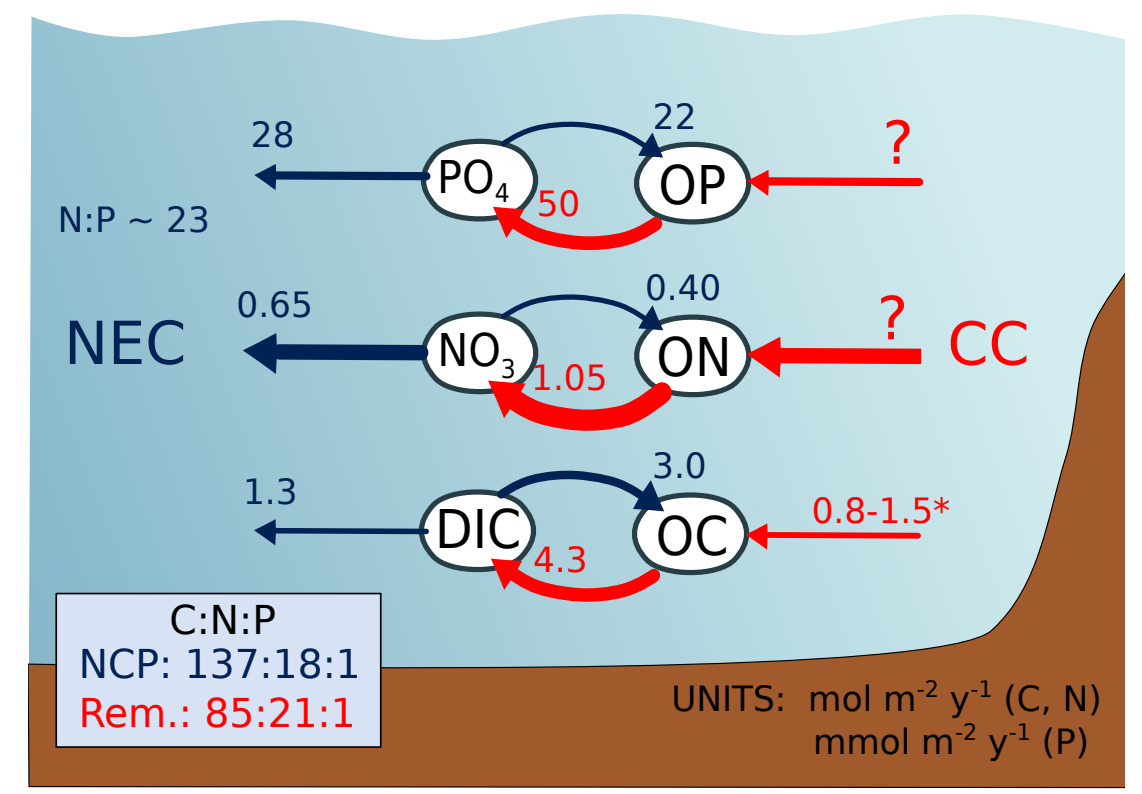

Figure 10: Schematic representation of the nutrient and carbon budgets in the Eastern boundary of the North Atlantic subtropical gyre. $\mathrm{PO}_{4}, \mathrm{NO}_{3}$ and DIC are phosphate, nitrate and dissolved inorganic carbon, respectively. $\mathrm{OP}, \mathrm{ON}$ and OC are organic phosphorus, nitrogen and carbon. CC and NEC are the Canary Current and the North Equatorial Current. The blue and red arrows connecting the inorganic and organic nutrient pools represent net community production (NCP) in the surface layer and remineralization in meso- and bathypegalic waters, respectively. The blue westward arrows represent the net flux (outputs - inputs) of inorganic nutrients and carbon out of the box, directed towards the open ocean with the NEC. The N:P ratio of this flux is indicated. The red eastward arrows represent the net supply of organic matter from the Canary Upwelling System. In order to highlight deviations from the Redfield stoichiometry in the different processes, the arrow widths have been approximately normalized to the Redfield proportions. The C:N:P molar ratios of NCP and remineralization are shown in a box in the bottom-left corner. Units are $\mathrm{mol} \mathrm{m}^{-2} \mathrm{yr}^{-1}$ for carbon and nitrogen and $\mathrm{mmol} \mathrm{m}^{-2} \mathrm{yr}^{-1}$ for phosphorus. * indicates the OC net flux reported by Alonso-González et al. (2009) and Lovecchio et al. (2017). $\mathrm{ON}$ and OP net fluxes are currently unknown.

rates of $5.6 \mathrm{~mol} \mathrm{O}_{2} \mathrm{~m}^{-2} \mathrm{yr}^{-1}$ calculated by Jenkins (1982) in the Beta Triangle, to the northwest of our box $\left(26.5^{\circ} \mathrm{N}-38.5^{\circ} \mathrm{W}, 32.5^{\circ} \mathrm{N}-30.0^{\circ} \mathrm{W}, 22.5^{\circ} \mathrm{N}-28.5^{\circ} \mathrm{W}\right)$, using the AOU distribution and ${ }^{3} \mathrm{H}-{ }^{3} \mathrm{He}$ water mass ages. They are also similar to the remineralization rates at the ESTOC site $(2.0-3.1$ mol C m$\left.~^{-2} \mathrm{yr}^{-1}\right)$, north of the Canary Islands $\left(29.1^{\circ} \mathrm{N}-15.5^{\circ} \mathrm{W}\right)$, obtained with a tracer conservation model and in vitro electron transport system activity (ETS) measurements (Fernández-Castro et al., 2016), and well within the range of a global compilation of ETS measurements (Arístegui et al., 2003a).

According to our results, the largest fraction of mesopelagic remineralization takes place in central waters $(100-700 \mathrm{~m})$. However, a local maximum of remineralization was found for all tracers in the upper intermediate layer at 700-1000 m (Figure 7). A compilation of in vitro ETS measurements, indicative of respiration processes, revealed that a similar feature was present around different ocean basins (Arístegui et al., 2003a). The reason for this feature was unknown and the authors speculated with the possibility that it was caused by migrating zooplankton. In our study region, the accumulation of shelf-produced particles in intermediate nepheloid layers has been reported in the depth range of the remineralization maximum (Karakaş et al., 2006, Fischer et al., 2009). Although we cannot discard that our model reveals the existence of an actual maximum of remineralization rates in intermediate waters, further verification would be required because remineralization rates in these layers were mainly 
determined by the vertical diffusion term and, as a consequence, rather uncertain.

Overall, the remineralization rates computed for the mesopelagic and deep waters exceeded the local rates of net production in the surface layer, pointing out that, in spite of the net autotrophy of the surface ocean, the full-depth metabolic balance of the study area is net heterotrophic (Figure 10). The same situation was found in the simulations of Lovecchio et al. (2017) for the ocean adjacent to the CanUS. The overall net nutrient deficit computed here from the surface to the bottom, considering the atmospheric sources, was $-0.65 \pm 0.36 \mathrm{~mol} \mathrm{~N} \mathrm{~m}^{-2} \mathrm{yr}^{-1}$ for nitrogen (equivalent to $-7.0 \pm 3.9 \times 10^{11}$ $\left.\mathrm{mol} \mathrm{Nyr}^{-1}\right)$ and $-28 \pm 21 \mathrm{mmol} \mathrm{P} \mathrm{m}^{-2} \mathrm{yr}^{-1}\left(-0.30 \pm 0.22 \times 10^{11} \mathrm{~mol} \mathrm{Pyr}^{-1}\right)$ for phosphorus, resulting in a high $\mathrm{N}: \mathrm{P} \sim 23.2$ of the nutrient deficit. Due to the high $\mathrm{C}: \mathrm{N}$ values of net production compared to remineralization, the carbon budget was close to balance, with a net deficit of $1.3 \pm 1.8 \mathrm{~mol} \mathrm{C} \mathrm{m}^{-2} \mathrm{yr}^{-1}$ $\left(-17 \pm 23 \mathrm{Tg} \mathrm{C}^{-1}\right)$ (Figure 10).

\subsection{Deviations from Redfield: causes}

Our nutrient budget calculations revealed strong deviations from the Redfield stoichiometry, particularly for mesopelagic respiration. In the central waters oxygen is consumed and inorganic carbon and nutrients are released with $-\mathrm{O}_{2}: \mathrm{C}: \mathrm{N}: \mathrm{P}$ proportions of 168:107:28:1, implying a strong preferential remineralization of organic nitrogen with respect to both carbon and phosphorus. As a result of these deviations, the region presents a stronger nitrate deficit, with respect to DIC and phosphate. In the case of carbon, horizontal advection of organic matter from the Canary Upwelling System could account for this deficit, as the available estimates of organic carbon transport to the open ocean are roughly coherent with the calculated demand. For example, Alonso-González et al. (2009) estimated a net input of POC advected by geostrophic and Ekman transport of $0.83 \mathrm{~mol} \mathrm{C} \mathrm{m}^{-2} \mathrm{yr}^{-1}$ to the surface and central waters of our study region. This should be considered a lower-end estimate because the contribution of DOC, which can be significant in the region (15-53\%) (Arístegui et al., 2003b, Santana-Falcón et al., 2017), was not quantified. On the other hand, Lovecchio et al. (2017) calculated that the net heterotrophic balance of the eastern NASTG was sustained by a net annual supply of $19 \mathrm{Tg} \mathrm{C}$ from the African shelf toward the open ocean, also comparable with our carbon deficit. Unfortunately, while the advection of organic carbon from the CanUS could explain this deficit, direct quantification of the organic nitrogen and phosphorus transport from the CanUS into the open ocean is currently lacking.

Previous studies, based mainly on modeling approaches, showed that allochthonous dissolved organic nitrogen (DON) and phosphorus (DOP) imported from the eastern flanks of the subtropical gyres can become available for phytoplankton communities within the photic zone, following bacterial degradation, and enhance export production of nitrogen (by 40\%) and phosphorus (by 70\%) within the oligotrophic gyres (Roussenov et al., 2006, Torres-Valdés et al., 2009). An enhancement of net production by DOM supply as suggested by these authors would raise our rates of net production of organic nitrogen and phosphorus in the epipelagic layer to $0.55 \mathrm{~mol} \mathrm{~N} \mathrm{~m}^{-2} \mathrm{yr}^{-1}$ and $37.7 \mathrm{mmol} \mathrm{P} \mathrm{m}^{-2} \mathrm{yr}^{-1}$, respectively, which would reduce the net nitrogen and phosphorus deficit to $-0.50 \mathrm{~mol} \mathrm{~N} \mathrm{~m}^{-2} \mathrm{yr}^{-1}$ and $-12.5 \mathrm{~mol} \mathrm{P} \mathrm{m}^{-2} \mathrm{yr}^{-1}$. This would drive the overall phosphorus budget closer to balance, but the nitrogen deficit would remain significant. An alternative pathway is that DOM subducts while drifting offshore and is remineralized directly in mesopelagic waters (Letscher et al., 2015). Other than DOM, slowly 
sinking organic particles advected from the CanUS have been shown to play a major role in the carbon cycle of the eastern NASTG, contributing directly to mesopelagic respiration (Alonso-González et al., 2009, 2010). Alonso-González et al. (2009) reported an increase of the C:N molar ratios of suspended organic matter with depth and toward the southwest of our study region in mesopelagic waters, suggesting that organic nitrogen is preferentially removed from particles as they sink and/or are advected with the CC-NEC. This observation is in agreement with the low $\mathrm{C}: \mathrm{N}$ ratios of mesopelagic remineralization found here.

The high N:P ratio $(=28)$ of remineralization in central waters and the net nitrate deficit require of a preferential removal of organic nitrogen with respect to phosphorus. Due to its lability, organic phosphorous is remineralized 1.3-2.2 times faster than nitrogen, and nitrogen 1.7-3.9 times faster than carbon (Lønborg and Álvarez-Salgado, 2012, Letscher et al., 2015). For this reason, aged dissolved organic matter is depleted in nitrogen with respect to carbon and in phosphorus with respect to nitrogen, in comparison with fresh materials (Hopkinson and Vallino, 2005). Considering this, the most reasonable explanation for the high N:P ratios of mesopelagic remineralization could be that the imported organic matter reaching this layer is sufficiently aged that it is already depleted in phosphorus ( $\mathrm{N}: \mathrm{P}>28)$, but it still contains sufficient bioavailable nitrogen. This situation implies a preferential removal of organic phosphorous during the transit of the organic materials from the NW African shelf to our study region, which is reasonable given the lability of organic phosphorus compounds. This is also supported by several field studies in the area. First, the analysis of the inorganic nutrient distribution in the CanUS at $30^{\circ} \mathrm{N}$ by Treguer and Le Corre (1979) revealed a preferential recycling of phosphorus over the Moroccan shelf with a N:P ratio of $11-12$. Furthermore, with a mixing analysis of inorganic nutrients over the coastal transition zone from the NW African shelf to $\sim 800 \mathrm{~km}$ offshore at the same latitude, Pérez et al. (2001) found that the average N:P molar ratio of remineralization was $13.8 \pm 0.7$, significantly lower than the Redfield ratio. Finally, Torres-Valdés et al. (2009) reported a N:P ratio of the dissolved organic matter of $\sim 23$ close to the NW African coast, and larger values increasing to $>30$ over the adjacent oligotrophic ocean, which is also compatible with the preferential removal of organic phosphorus during export to the open ocean.

Now we investigate whether the phosphorus remineralization rates required to increase the N:P ratio of organic matter to 28 are realistic, and supported by the in situ measurements of DOP consumption reported by Reynolds et al. (2014). We consider a net production rate of $750 \mathrm{~g} \mathrm{C} \mathrm{m}^{-2} \mathrm{yr}^{-1}$ in the CanUS (Arístegui et al., 2006) and a export ratio of 0.5, typical of upwelling systems. A part of the organic matter available for export is composed by fast sinking organic particles that are not advected offshore. According to Arístegui et al. (2003b), 30\% of the mesopelagic respiration in the coastal transition zone of the CanUS is sustained by DOC, while $34-59 \%$ is sustained by non-sinking POC (Alonso-González et al., 2009). Thus, at best $90 \%$ of the export production $\left(28.1 \mathrm{~mol} \mathrm{C} \mathrm{m}^{-2} \mathrm{yr}^{-1}\right)$ is prone to be transported towards the subtropical gyre. According to Martiny et al. (2013), the C:N:P ratios of the organic matter available for export in upwelling systems is $137: 18: 1$, with which $0.21 \mathrm{~mol} \mathrm{P} \mathrm{m}^{-2} \mathrm{yr}^{-1}$ of organic phosphorus would be exported towards the open ocean. After leaving the shelf, the organic materials continue to be degraded, with phosphorus compounds being removed faster, increasing the N:P ratio. By applying the decay constants for dissolved organic $\mathrm{C}, \mathrm{N}$ and $\mathrm{P}$ in mesopelagic waters reported by 

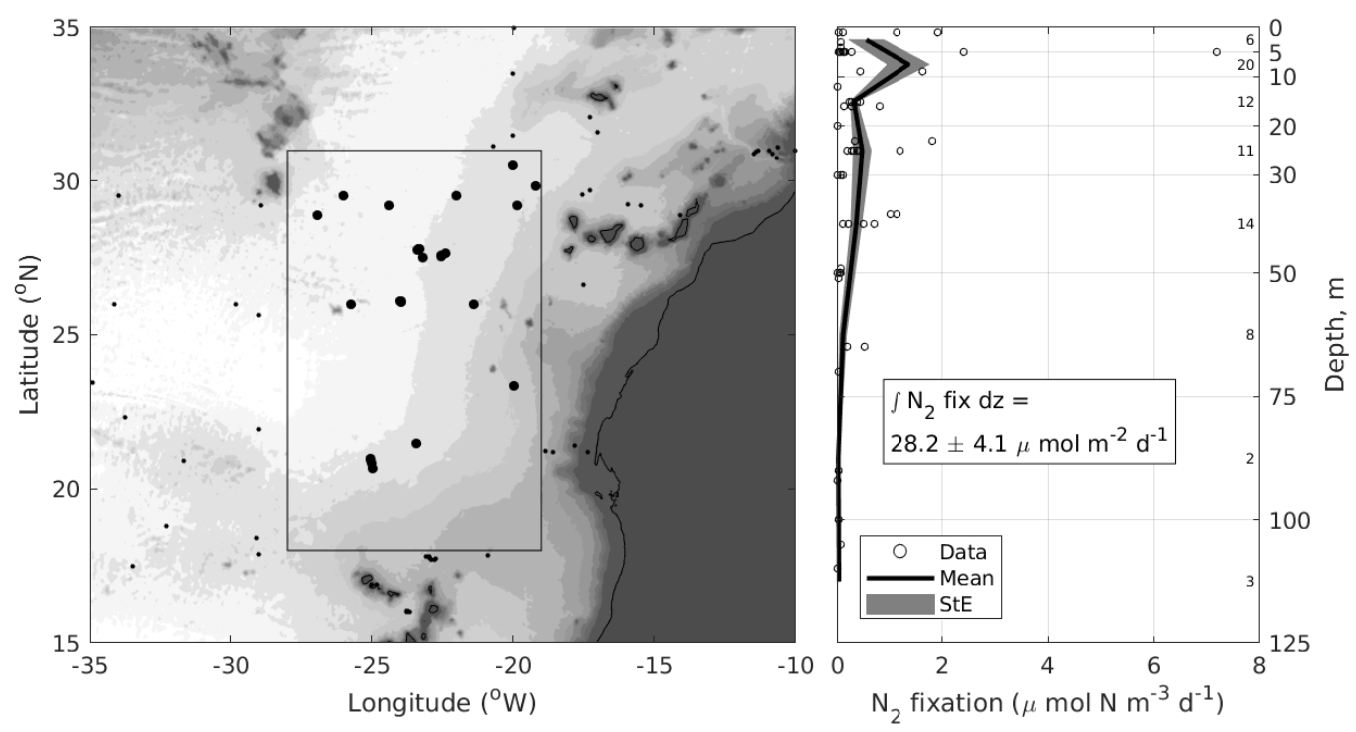

Figure 11: Biological nitrogen $\left(\mathrm{N}_{2}\right)$ fixation rates inside the model box from the Luo et al. (2012) climatology. Sampling locations inside the box are represented by large black dots in the left panel. An average depth-integrated $\mathrm{N}_{2}$ fixation rate was calculated by averaging the available measurements over defined depth intervals (right panel). The number of data points in each depth interval is shown in the right side of the plot.

Letscher et al. (2015), the exported organic matter would reach a N:P ratio of 28 after about 245 days. Assuming a mean velocity of $1 \mathrm{~cm} \mathrm{~s}^{-1}$ (see Figure 4), the distance travelled by the organic materials over that time spam would be about $210 \mathrm{~km}$, which is roughly the distance from the NW African shelf to the eastern boundary of the box. By the time the N:P ratio of 28 is reached, $0.12 \mathrm{~mol} \mathrm{P} \mathrm{m}^{-2} \mathrm{yr}^{-1}$ of the organic phosphorus would have been remineralized. This consumption rate is equivalent to $1.6 \mathrm{nM} \mathrm{P} \mathrm{d}^{-1}$ when integrated over a depth range of $\sim 200$ m, i.e. the upper thermocline. Reynolds et al. (2014) measured in situ DOP uptake rates in the surface waters of the eastern NASTG of $8.0 \pm 7.3 \mathrm{nM} \mathrm{P} \mathrm{d}^{-1}$, which were in excess of the local production of $6.9 \pm 4.4 \mathrm{nMPd}^{-1}$ by $\sim 1.1 \mathrm{nMPd}^{-1}$, compatible with the required organic phosphorus drawdown.

Other than the supply of organic matter from the CanUS, biological nitrogen fixation could help to explain the high $\mathrm{N}: \mathrm{P}$ and low $\mathrm{O}_{2}: \mathrm{N}$ ratios of mesopelagic respiration and the overall nitrogen deficit. The large-scale distribution of this process in the North Atlantic is believed to be controlled by iron availability (Moore et al., 2009), mostly determined by atmospheric deposition of dust originated in the Sahara desert. The vicinity of our study region to the iron source could, in principle, favour this process. By using in situ measurements of nitrogen fixation compiled by Luo et al. (2012), we derived a mean depthintegrated fixation rate of $0.01 \mathrm{~mol} \mathrm{~N} \mathrm{~m}^{-2} \mathrm{yr}^{-1}$ in our study area (Figure 11). This rate is rather small and insufficient to account for the nitrogen deficit, possibly because the main area for iron deposition and enhanced nitrogen fixation is located to the south of our study region, determined by the atmospheric circulation (Schlosser et al., 2014). However, a more important contribution of nitrogen fixation can not be completely ruled out as nitrogen fixation measurements from bottle incubations, as those used here, can possibly underestimate the actual rates (Mohr et al., 2010, Bombar et al., 2018). Furthermore, dark nitrogen fixation, which is now emerging as a relevant biogeochemical process (Benavides et al., 2018), 
has not been considered due to the lack of measurements in the area.

\subsection{Deviations from Redfield: implications}

Mesopelagic remineralization occurring at high $\mathrm{N}: \mathrm{P}$ is a well known feature of the (sub)tropical North Atlantic, and it is reflected in the high ambient $\mathrm{NO}_{3}: \mathrm{PO}_{4}$ ratios, or positive values of the DINxs (DINxs $=\mathrm{NO}_{3}-16 \cdot \mathrm{PO}_{4}$ ) tracer, found in thermocline waters (Michaels et al., 1996). Initially, this anomaly was attributed to the remineralization of high N:P organic matter produced during nitrogen fixation (Gruber and Sarmiento, 1997, Hansell et al., 2004a). However, more recent works have added a number of other processes that are likely co-responsible for this feature, including atmospheric nitrogen deposition (Zamora et al., 2010) and the remineralization of phosphorous-depleted organic matter (Wu et al., 2000, Hansell et al., 2007, Landolfi et al., 2008, Monteiro and Follows, 2012). Here we quantify the contribution of the eastern boundary to the DINxs formation in the North Atlantic and, using literature data, we assess the potential contribution of nitrogen fixation and atmospheric deposition vs. the recycling of P-depleted organic matter to the formation of this structure.

Due to the non-Redfield cycling in the central waters, our box produced an excess nitrate $\left(J_{\mathrm{DINxs}}=\right.$ $J_{\mathrm{NO}_{3}}-16 J_{\mathrm{PO}_{4}}$ ) of $0.20 \pm 0.15 \mathrm{~mol} \mathrm{~N} \mathrm{~m}^{-2} \mathrm{yr}^{-1}$, equivalent to $2.2 \pm 1.6 \times 10^{11} \mathrm{~mol} \mathrm{~N} \mathrm{yr}^{-1}$. This figure represents $\sim 30 \%$ of the total DINxs production estimated for the subtropical North Atlantic $(7.8 \pm 1.7 \times$ $10^{11} \mathrm{~mol} \mathrm{yr}^{-1}$ ) (Hansell et al., 2007). Using the nitrogen fixation rate derived in Figure 11 and assuming a N:P ratio of 40 for the organic matter produced during nitrogen fixation (Mahaffey et al., 2005), we estimated a minor contribution $\left(0.11 \times 10^{11} \mathrm{~mol} \mathrm{~N} \mathrm{yr}^{-1}\right)$ of this process in the eastern NASTG, in good agreement with Benavides et al. (2013). The deposition of reactive nitrogen is at a minimum $(<0.01$ mol $\left.\mathrm{Nm}^{-2} \mathrm{yr}^{-1}\right)$ in the eastern NASTG, while phosphorus deposition is at a maximum $(0.067-1.6$ $\left.\mathrm{mmol} \mathrm{P} \mathrm{m} \mathrm{yr}^{-1}\right)$. Even if the lower range estimate for the phosphorus flux was used, resulting in a very large N:P $(\sim 150)$ ratio for the deposition flux, the potential contribution of this process to the DINxs production was similarly low $\left(0.096 \times 10^{11} \mathrm{~mol} \mathrm{~N} \mathrm{yr}^{-1}\right)$. Unless large underestimation of nitrogen fixation rates from bottle incubations is confirmed (Mohr et al., 2010, Bombar et al., 2018), the DINxs production in our box must be caused, almost exclusively, by the import and remineralization of organic matter that has become phosphorus-depleted during its transit from the NW African shelf to the open ocean. In fact, our rate of DINxs production is in close agreement with the fraction of the total production attributed to dissolved organic matter in the subtropical North Atlantic, according to Hansell et al. (2007).

\section{Conclusions}

Using an inverse box model approach we investigated the cycling of oxygen, carbon and nutrients (nitrate, phosphate) and the rates of net biological production and remineralization in the eastern boundary of the North Atlantic subtropical gyre. Our results showed that the euphotic waters of the study region were net autotrophic but the rates of mesopelagic and bathypelagic respiration exceeded net production. This fact resulted in a material deficit for carbon and nutrients in the area, which could be possibly compensated by the supply of organic matter from the NW African shelf. Due to a strong preferential remineralization of organic nitrogen in mesopelagic waters, we computed a significant generation of 
excess nitrate which was exported towards the interior of the gyre, potentially impacting the DINxs distribution in the whole North Atlantic subtropical gyre. At the same time, the eastern boundary was left behind with an important nitrogen deficit, which we could not explain with the rates of nitrogen fixation available in the current literature. Alternatively, we identify the supply of high N:P organic matter from the CanUS as a potential candidate to close the nitrogen balance and explain the production of DINxs in the region. Hence, our results put forward the need of further research to quantify the stoichiometry and offshore transport organic nutrients in the Canary Upwelling System.

\section{Acknowledgements}

B. Fernández-Castro acknowledges the funding of a Juan de la Cierva-Formación fellowship (FJCI2015-25712) from the Spanish Ministry of Economy and Competitiveness. Funding for this study was provided by the Spanish Ministry of Economy and Competitiveness under the research project FLUXES (CTM2015-69392-C3-2-R, PI X. A. Álvarez-Salgado) and by the Xunta de Galicia under the research project VARITROP (09MDS001312PR, PI B. Mouriño-Carballido). We thank all the researchers and technicians involved in the data collection and elaboration of the World Ocean Atlas 2013. The manuscript benefited from the comments of two anonymous reviewers.

\section{References}

Alonso-González, I. J., Arístegui, J., Lee, C., Sanchez-Vidal, A., Calafat, A., Fabrés, J., Sangrá, P., Masqué, P., Hernández-Guerra, A., and Benítez-Barrios, V. (2010). Role of slowly settling particles in the ocean carbon cycle. Geophys. Res. Lett., 37(13):L13608.

Alonso-González, I. J., Arístegui, J., Vilas, J. C., and Hernández-Guerra, A. (2009). Lateral POC transport and consumption in surface and deep waters of the Canary Current region: A box model study. Global Biogeochem. Cycles, 23(2):GB2007.

Álvarez, M., Pérez, F., Shoosmith, D. R., and Bryden, H. L. (2005). Unaccounted role of Mediterranean Water in the drawdown of anthropogenic carbon. J. Geophys. Res. C Ocean., 110(9):1-18.

Álvarez-Salgado, X., Álvarez, M., Brea, S., Mèmery, L., and Messias, M. (2014). Mineralization of biogenic materials in the water masses of the South Atlantic Ocean. II: Stoichiometric ratios and mineralization rates. Prog. Oceanogr., 123.

Álvarez-Salgado, X. A., Arístegui, J., Barton, E. D., and Hansell, D. A. (2007). Contribution of upwelling filaments to offshore carbon export in the subtropical Northeast Atlantic Ocean. Limnol. Oceanogr., 52(3):1287-1292.

Anderson, L. A. (1995). On the hydrogen and oxygen content of marine phytoplankton. Deep Sea Res. $I, 42(1): 1675-1680$.

Anderson, L. A. and Sarmiento, J. L. (1994). Redfield ratios of remineralization determined by nutrient data analysis. Global Biogeochem. Cycles, 8(1):65-80. 
Arhan, M., Colin de Verdière, A., and Mémery, L. (1994). The eastern boundary of the subtropical North Atlantic. Am. Meteorol. Soc., 24:1295-1316.

Arístegui, J., Agustí, S., and Duarte, C. M. (2003a). Respiration in the dark ocean. Geophys. Res. Lett., 30(2):1-4.

Arístegui, J., Alvarez-Salgado, X. A., Barton, E. D., Figueiras, F. G., Hernández-León, S., Roy, C., and Santos, A. M. P. (2006). Oceanography and fisheries of the Canary Current/Iberian region of the eastern North Atlantic. In Robinson, A. R. and Brink, K. H., editors, Sea, volume 14, pages 877-931. Harvard University Press.

Arístegui, J., Barton, E. D., Montero, M. F., Garcia-Muñoz, M., and Escánez, J. (2003b). Organic carbon distribution and water column respiration in the NW Africa-Canaries Coastal Transition Zone. Aquat. Microb. Ecol., 33:289-301.

Auger, P. A., Gorgues, T., Machu, E., Aumont, O., and Brehmer, P. (2016). What drives the spatial variability of primary productivity and matter fluxes in the north-west African upwelling system? A modelling approach. Biogeosciences, 13(23):6419-6440.

Barth, J. A. (2002). Injection of carbon from the shelf to offshore beneath the euphotic zone in the California Current. J. Geophys. Res., 107(C6):3057.

Barton, E. D., Arístegui, J., Tett, P., and Navarro-Pérez, E. (2004). Variability in the Canary Islands area of filament-eddy exchanges. Prog. Oceanogr., 62(2-4):71-94.

Benavides, M., Arístegui, J., Agawin, N. S., Álvarez-Salgado, X. A., Álvarez, M., and Troupin, C. (2013). Low contribution of N2 fixation to new production and excess nitrogen in the subtropical northeast Atlantic margin. Deep Sea Res. Part I Oceanogr. Res. Pap., 81(3):36-48.

Benavides, M., Shoemaker, K. M., Moisander, P. H., Niggemann, J., Dittmar, T., Duhamel, S., Grosso, O., Pujo-Pay, M., Hélias-Nunige, S., and Bonnet, S. (2018). Aphotic N2 fixation along an oligotrophic to ultraoligotrophic transect in the Western Tropical South Pacific Ocean. Biogeosciences, 15:31073119 .

Bombar, D., Paerl, R. W., Anderson, R., and Riemann, L. (2018). Filtration via Conventional Glass Fiber Filters in 15N2 Tracer Assays Fails to Capture All Nitrogen-Fixing Prokaryotes. Front. Mar. Sci., 5:1-11.

Bory, A., Jeandel, C., Leblond, N., Vangriesheim, A., Khripounoff, A., Beaufort, L., Rabouille, C., Nicolas, E., Tachikawa, K., Etcheber, H., and Buat-Ménard, P. (2001). Downward particle fluxes within different productivity regimes off the Mauritanian upwelling zone (EUMELI program). Deep. Res. Part I Oceanogr. Res. Pap., 48(10):2251-2282.

Bryan, K., Dukowicz, J. K., and Smith, R. D. (1999). On the Mixing Coefficient in the Parameterization of Bolus Velocity. J. Phys. Oceanogr., 29(9):2442-2456. 
Capone, D. G., Burns, J. a., Montoya, J. P., Subramaniam, A., Mahaffey, C., Gunderson, T., Michaels, A. F., and Carpenter, E. J. (2005). Nitrogen fixation by Trichodesmium spp.: An important source of new nitrogen to the tropical and subtropical North Atlantic Ocean. Global Biogeochem. Cycles, 19(2):GB2024.

Carr, M. E. (2002). Estimation of potential productivity in Eastern Boundary Currents using remote sensing. Deep. Res. Part II Top. Stud. Oceanogr., 49(1-3):59-80.

Carracedo, L. I., Gilcoto, M., Mercier, H., and Pérez, F. F. (2014). Seasonal dynamics in the AzoresGibraltar Strait region: A climatologically-based study. Prog. Oceanogr., 122:116-130.

Carracedo Segade, L. I., Gilcoto, M., Mercier, H., and Pérez, F. F. (2015). Quasi-synoptic transport, budgets and water mass transformation in the Azores-Gibraltar Strait region during summer 2009. Prog. Oceanogr., 130:47-65.

Chelton, D. B., DeSzoeke, R. A., Schlax, M. G., El Naggar, K., and Siwertz, N. (1998). Geographical Variability of the First Baroclinic Rossby Radius of Deformation. J. Phys. Oceanogr., 28(3):433-460.

del Giorgio, P. A. and Duarte, C. M. (2002). Respiration in the open ocean. Nature, 420(6914):379-384.

Doval, M. D., Álvarez-Salgado, X. A., and Pérez, F. F. (2001). Organic matter distributions in the Eastern North Atlantic-Azores Front region. J. Mar. Syst., 30(1-2):33-49.

Duarte, C. M. and Agustí, S. (1998). The CO2 Balance of Unproductive Aquatic Ecosystems. Science (80-. )., 281(5374):234-236.

Duarte, C. M., Agustí, S., Arístegui, J., González, N., and Anadón, R. (2001). Evidence for a heterotrophic subtropical northeast Atlantic. Limnol. Oceanogr., 46(2):425-428.

Duarte, C. M., Regaudie-de Gioux, A., Arrieta, J. M., Delgado-Huertas, A., and Agustí, S. (2013). The Oligotrophic Ocean Is Heterotrophic. Ann. Rev. Mar. Sci., 5(1):551-569.

Duce, R. A., LaRoche, J., Altieri, K., Arrigo, K. R., Baker, A. R., Capone, D. G., Cornell, S., Dentener, F., Galloway, J., Ganeshram, R. S., Geider, R. J., Jickells, T., Kuypers, M. M., Langlois, R., Liss, P. S., Liu, S. M., Middelburg, J. J., Moore, C. M., Nickovic, S., Oschlies, A., Pedersen, T., Prospero, J., Schlitzer, R., Seitzinger, S., Sorensen, L. L., Uematsu, M., Ulloa, O., Voss, M., Ward, B., and Zamora, L. (2008). Impacts of Atmospheric Anthropogenic Nitrogen on the Open Ocean. Science (80-. )., 320(5878):893-897.

Emerson, S. (2014). Annual net community production and the biological carbon flux in the ocean. Global Biogeochem. Cycles, 28(1):14-28.

Emerson, S. and Bushinsky, S. (2016). The role of bubbles during air-sea gas exchange. J. Geophys. Res. Ocean., 121(6):4360-4376.

Eppley, R. W. and Peterson, B. J. (1979). Particulate organic matter flux and planktonic new production in the deep ocean. Nature, 282(5740):677-680. 
Fernández-Castro, B., Anderson, L., Marañón, E., Neuer, S., Ausín, B., Gonzáez-Dávila, M., SantanaCasiano, J., Cianca, A., Santana, R., Llinás, O., Rueda, M., and Mouriño-Carballido, B. (2012). Regional differences in modelled net production and shallow remineralization in the North Atlantic subtropical gyre. Biogeosciences, 9(8).

Fernández-Castro, B., Arístegui, J., Anderson, L., Montero, M., Hernández-León, S., Marañón, E., and Mouriño-Carballido, B. (2016). Mesopelagic respiration near the ESTOC (European Station for Time-Series in the Ocean, $15.5^{\circ} \mathrm{W}, 29.1^{\circ} \mathrm{N}$ ) site inferred from a tracer conservation model. Deep. Res. Part I Oceanogr. Res. Pap., 115.

Ferreira, M. L. d. C. and Kerr, R. (2017). Source water distribution and quantification of North Atlantic Deep Water and Antarctic Bottom Water in the Atlantic Ocean. Prog. Oceanogr., 153:66-83.

Fischer, G., Reuter, C., Karakas, G., Nowald, N., and Wefer, G. (2009). Offshore advection of particles within the Cape Blanc filament, Mauritania: Results from observational and modelling studies. Prog. Oceanogr., 83(1-4):322-330.

Fraga, F., Rios, A. F., Perez, F. F., and Figueiras, F. G. (1998). Theoretical limits of oxygen : carbon and oxygen : nitrogen ratios during photosynthesis and mineralisation of organic matter in the sea. Sci. Mar., 62(1-2):161-168.

Gabric, A. J., García, L., Van Camp, L., Nykjaer, L., Eifler, W., and Schrimpf, W. (1993). Offshore Export of Shelf Production in the Cape Blanc (Mauritania) Giant Filament as Derived From Coastal Zone Color Scanner Imagery. J. Geophys. Res., 98(92):4697-4712.

Ganachaud, A. (2003). Large-scale mass transports, water mass formation, and diffusivities estimated from World Ocean Circulation Experiment (WOCE) hydrographic data. J. Geophys. Res., 108(C7):3213.

Ganachaud, A. and Wunsch, C. (2002). Oceanic nutrient and oxygen transports and bounds on export production during the World Ocean Circulation Experiment. Global Biogeochem. Cycles, 16(4):5-1$5-14$.

Garcia, H. E., Boyer, T. P., Locarnini, R. A., Antonov, J. I., Mishonov, A. V., Baranova, O. K., Zweng, M. M., Reagan, J. R., and Johnson, D. R. (2013a). World Ocean Atlas 2013. Volume 3: dissolved oxygen, apparent oxygen utilization, and oxygen saturation. NOAA Atlas NESDIS 75, 3(September): 27.

Garcia, H. E., Locarnini, R. A., Boyer, T. P., Antonov, J. I., Baranova, O. K., Zweng, M. M., Reagan, J. R., and Johnson, D. R. (2013b). World Ocean Atlas 2013, Volume 4 : Dissolved Inorganic Nutrients (phosphate, nitrate, silicate). NOAA Atlas NESDIS 76, 4(September):27 pp.

García-Ibáñez, M. I., Pardo, P. C., Carracedo, L. I., Mercier, H., Lherminier, P., Ríos, A. F., and Pérez, F. F. (2015). Structure, transports and transformations of the water masses in the Atlantic Subpolar Gyre. Prog. Oceanogr., 135:18-36. 
García-Muñoz, M., Arístegui, J., Montero, M. F., and Barton, E. D. (2004). Distribution and transport of organic matter along a filament-eddy system in the Canaries - NW Africa coastal transition zone region. Prog. Oceanogr., 62(2-4):115-129.

García-Muñoz, M., Arístegui, J., Pelegrí, J. L., Antoranz, A., Ojeda, A., and Torres, M. (2005). Exchange of carbon by an upwelling filament off Cape Ghir (NW Africa). J. Mar. Syst., 54(1-4 SPEC. ISS.):83-95.

González-Dávila, M., Santana-Casiano, J. M., and González-Dávila, E. F. (2007). Interannual variability of the upper ocean carbon cycle in the northeast Atlantic Ocean. Geophys. Res. Lett., 34(7):L07608.

Gruber, N. and Sarmiento, J. (1997). Global patterns of marine nitrogen fixation and denitrification. Global Biogeochem. Cycles, 11(2):235-266.

Hansell, D., Olson, D., Dentener, F., and Zamora, L. (2007). Assessment of excess nitrate development in the subtropical North Atlantic. Mar. Chem., 106(3-4):562-579.

Hansell, D. A., Bates, N. R., and Olson, D. B. (2004a). Excess nitrate and nitrogen fixation in the North Atlantic Ocean. Mar. Chem., 84(3-4):243-265.

Hansell, D. A., Ducklow, H. W., Macdonald, A. M., and O-Neil Baringer, M. (2004b). Metabolic poise in the North Atlantic Ocean diagnosed from organic matter transports. Limnol. Oceanogr., 49(4):1084-1094.

Harvey, J. (1982). $\theta$-S relationships and water masses in the eastern North Atlantic. Deep Sea Res. Part A, Oceanogr. Res. Pap., 29(8):1021-1033.

Helmke, P., Romero, O., and Fischer, G. (2005). Northwest African upwelling and its effect on offshore organic carbon export to the deep sea. Global Biogeochem. Cycles, 19(4):1-16.

Hernández-Guerra, A., Espino-Falcón, E., Vélez-Belchí, P., Dolores Pérez-Hernández, M., MartínezMarrero, A., and Cana, L. (2017). Recirculation of the Canary Current in fall 2014. J. Mar. Syst., 174(May):25-39.

Hernández-Guerra, A., Fraile-Nuez, E., López-Laatzen, F., Martínez, A., Parrilla, G., and Vélez-Belchí, P. (2005). Canary Current and North Equatorial Current from an inverse box model. J. Geophys. Res. Ocean., 110(12):1-16.

Ho, D. T., Law, C. S., Smith, M. J., Schlosser, P., Harvey, M., and Hill, P. (2006). Measurements of air-sea gas exchange at high wind speeds in the Southern Ocean: Implications for global parameterizations. Geophys. Res. Lett., 33(16):1-6.

Hopkinson, C. and Vallino, J. (2005). Efficient expert of carbon to the deep ocean through dissolved organic matter. Nature, 433(January):142-145.

Inthorn, M., Wagner, T., Scheeder, G., and Zabel, M. (2006). Lateral transport controls distribution, quality, and burial of organic matter along continental slopes in high-productivity areas. Geology, 34(3):205-208. 
Iorga, M. C. and Lozier, M. S. (1999). Signatures of the Mediterranean outflow from a North Atlantic climatology: 2. Diagnostic velocity fields. J. Geophys. Res. Ocean., 104(C11):26011-26029.

Jackett, D. R. and McDougall, T. J. (1997). A Neutral Density Variable for the World's Oceans. J. Phys. Oceanogr., 27(2):237-263.

Jackson, D. D. (1979). The use of a priori data to resolve non-uniqueness in linear inversion. Geophys. J. R. Astron. Soc., 57(1):137-157.

Jenkins, W. J. (1982). Oxygen utilization rates in North Atlantic subtropical gyre and primary production in oligotrophic systems. Nature, 300(5889):246-248.

Jenkins, W. J. and Doney, S. C. (2003). The subtropical nutrient spiral. Global Biogeochem. Cycles, 17(4):1110.

Jickells, T. D., Buitenhuis, E., Altieri, K., Baker, A. R., Fennel, K., Kanakidou, M. ., Laroche, J., Lee, K., Liss, P., and Middelburg, J. J. (2017). A re-evaluation of the magnitude and impacts of anthropogenic atmospheric nitrogen inputs on the ocean. Global Biogeochem. Cycles, 31:289-305.

Kähler, P., Oschlies, A., Dietze, H., and Koeve, W. (2010). Oxygen, carbon, and nutrients in the oligotrophic eastern subtropical North Atlantic. Biogeosciences, 7(3):1143-1156.

Karakaş, G., Nowald, N., Blaas, M., Marchesiello, P., Frickenhaus, S., and Schlitzer, R. (2006). Highresolution modeling of sediment erosion and particle transport across the northwest African shelf. $J$. Geophys. Res. Ocean., 111(6):1-13.

Keeling, R. F., Najjar, R. P., Bender, M. L., and Tans, P. P. (1993). What atmospheric oxygen measurements can tell us about the global carbon cycle. Global Biogeochem. Cycles, 7(1):37-67.

Landolfi, A., Dietze, H., and Volpe, G. (2016). Longitudinal variability of organic nutrients in the North Atlantic subtropical gyre. Deep. Res. Part I Oceanogr. Res. Pap., 111:50-60.

Landolfi, A., Oschlies, A., and Sanders, R. (2008). Organic nutrients and excess nitrogen in the North Atlantic subtropical gyre. Biogeosciences, 5:1199-1213.

Letscher, R. T. and Moore, J. K. (2017). Modest net autotrophy in the oligotrophic ocean. Global Biogeochem. Cycles, 31(4):699-708.

Letscher, R. T., Moore, J. K., Teng, Y. C., and Primeau, F. (2015). Variable C : N : P stoichiometry of dissolved organic matter cycling in the Community Earth System Model. Biogeosciences, 12(1):209221.

Letscher, R. T., Primeau, F., and Moore, J. K. (2016). Nutrient budgets in the subtropical ocean gyres dominated by lateral transport. Nat. Geosci., 9(11):815-819.

Lewis, M. R., Hebert, D., Harrison, W. G., Platt, T., and Oakey, N. S. (1986). Vertical nitrate fluxes in the oligotrophic ocean. Science (80-. )., 234:870-873. 
Liang, J. H., Deutsch, C., McWilliams, J. C., Baschek, B., Sullivan, P. P., and Chiba, D. (2013). Parameterizing bubble-mediated air-sea gas exchange and its effect on ocean ventilation. Global Biogeochem. Cycles, 27(3):894-905.

Liss, P. S. and Melivat, L. (1986). Air-Sea Gas exchange rates: Introduction and synthesis. In BuatMenard, P., editor, Role Air-Sea Exch. Geochemical Cycl., pages 113-127. D Reidel, Dordrecht.

Liu, K.-K., Atkinson, L., Quiñones, R., and Talaue-McManus, L., editors (2010). Carbon and nutrient fluxes in continental margins: a global synthesis. Springer Verlag.

Locarnini, R. A., Mishonov, A. V., Antonov, J. I., Boyer, T. P., Garcia, H. E., Baranova, O. K., Zweng, M. M., Paver, C. R., Reagan, J. R., Johnson, D. R., Hamilton, M., and Seidov, D. (2013). World Ocean Atlas 2013. Vol. 1: Temperature. S. Levitus, Ed.; A. Mishonov, Tech. Ed.; NOAA Atlas NESDIS, 73(September):40.

Lønborg, C. and Álvarez-Salgado, X. A. (2012). Recycling versus export of bioavailable dissolved organic matter in the coastal ocean and efficiency of the continental shelf pump. Global Biogeochem. Cycles, 26(3):GB3018.

Lovecchio, E., Gruber, N., and Münnich, M. (2018). Mesoscale contribution to the long-range offshore transport of organic carbon from the Canary Upwelling System to the open North Atlantic. Biogeosciences, 15:5061-2018.

Lovecchio, E., Gruber, N., Münnich, M., and Lachkar, Z. (2017). On the long-range offshore transport of organic carbon from the Canary Upwelling System to the open North Atlantic. Biogeosciences, 14(13):3337-3369.

Luo, Y.-W., Doney, S. C., Anderson, L. a., Benavides, M., Berman-Frank, I., Bode, A., Bonnet, S., Boström, K. H., Böttjer, D., Capone, D. G., Carpenter, E. J., Chen, Y. L., Church, M. J., Dore, J. E., Falcón, L. I., Fernández, A., Foster, R. a., Furuya, K., Gómez, F., Gundersen, K., Hynes, a. M., Karl, D. M., Kitajima, S., Langlois, R. J., LaRoche, J., Letelier, R. M., Marañón, E., McGillicuddy, D. J., Moisander, P. H., Moore, C. M., Mouriño-Carballido, B., Mulholland, M. R., Needoba, J. a., Orcutt, K. M., Poulton, a. J., Rahav, E., Raimbault, P., Rees, a. P., Riemann, L., Shiozaki, T., Subramaniam, A., Tyrrell, T., Turk-Kubo, K. a., Varela, M., Villareal, T. a., Webb, E. a., White, a. E., Wu, J., and Zehr, J. P. (2012). Database of diazotrophs in global ocean: abundance, biomass and nitrogen fixation rates. Earth Syst. Sci. Data, 4(1):47-73.

Machín, F., Hernández-Guerra, a., and Pelegrí, J. L. (2006). Mass fluxes in the Canary Basin. Prog. Oceanogr., 70(2-4):416-447.

Machín, F. and Pelegrí, J. L. (2009). Northward Penetration of Antarctic Intermediate Water off Northwest Africa. J. Phys. Oceanogr., 39(3):512-535.

Mahaffey, C., Michaels, A. F., and Capone, D. G. (2005). The conundrum of marine N2 fixation. Am. J. Sci., 305(6-8 SPEC. ISS.):546-595. 
Mahowald, N., Jickells, T. D., Baker, A. R., Artaxo, P., Benitez-Nelson, C. R., Bergametti, G., Bond, T. C., Chen, Y., Cohen, D. D., Herut, B., Kubilay, N., Losno, R., Luo, C., Maenhaut, W., McGee, K. a., Okin, G. S., Siefert, R. L., and Tsukuda, S. (2008). Global distribution of atmospheric phosphorus sources, concentrations and deposition rates, and anthropogenic impacts. Global Biogeochem. Cycles, 22(4):GB4026.

Martiny, A. C., Pham, C. T. a., Primeau, F. W., Vrugt, J. a., Moore, J. K., Levin, S. a., and Lomas, M. W. (2013). Strong latitudinal patterns in the elemental ratios of marine plankton and organic matter. Nat. Geosci., 6(4):279-283.

McCartney, M. S., Bennett, S. L., and Woodgate-Jones, M. E. (1991). Eastward Flow through the MidAtlantic Ridge at $11^{\circ} \mathrm{N}$ and Its Influence on the Abyss of the Eastern Basin. J. Phys. Oceanogr., 21(8):1089-1121.

Mercier, H. (1986). Determining the general circulation of the ocean: a nonlinear inverse problem. $J$. Geophys. Res., 91(C4):5103-5109.

Meunier, T., Barton, E. D., Barreiro, B., and Torres, R. (2012). Upwelling filaments off Cap Blanc: Interaction of the NW african upwelling current and the Cape Verde frontal zone eddy field? $J$. Geophys. Res. Ocean., 117(8):1-18.

Michaels, A. F., Olson, D., Sarmiento, J. L., Ammerman, J. W., Fanning, K., Jahnke, R., Knap, A. H., Lipschultz, F., and Prospero, J. M. (1996). Inputs, losses and transformations of nitrogen and phosphorus in the pelagic North Atlantic Ocean. Biogeochemistry, 35(1):181-226.

Mohr, W., Grosskopf, T., Wallace, D. W. R., and LaRoche, J. (2010). Methodological underestimation of oceanic nitrogen fixation rates. PLoS One, 5(9):1-7.

Monteiro, F. M. and Follows, M. J. (2012). On nitrogen fixation and preferential remineralization of phosphorus. Geophys. Res. Lett., 39(6):L06607.

Moore, M. C., Mills, M. M., Achterberg, E. P., Geider, R. J., LaRoche, J., Lucas, M. I., McDonagh, E. L., Pan, X., Poulton, A. J., Rijkenberg, M. J. A., Suggett, D. J., Ussher, S. J., and Woodward, E. M. S. (2009). Large-scale distribution of Atlantic nitrogen fixation controlled by iron availability. Nat. Geosci., 2(12):867-871.

Nagai, T., Gruber, N., Frenzel, H., Lachkar, Z., McWilliams, J. C., and Plattner, G.-K. (2015). Dominant role of eddies and filaments in the offshore transport of carbon and nutrients in the California Current System. J. Geophys. Res. Ocean., 120(8):5318-5341.

Neuer, S., Cianca, A., Helmke, P., Freudenthal, T., Davenport, R., Meggers, H., Knoll, M., SantanaCasiano, J. M., González-Davila, M., Rueda, M.-J., and Llinás, O. (2007). Biogeochemistry and hydrography in the eastern subtropical North Atlantic gyre. Results from the European time-series station ESTOC. Prog. Oceanogr., 72(1):1-29. 
Neuer, S., Freudenthal, T., Davenport, R., Llinás, O., and Rueda, M. J. (2002). Seasonality of surface water properties and particle flux along a productivity gradient off NW Africa. Deep. Res. Part II Top. Stud. Oceanogr., 49(17):3561-3576.

Nightingale, D., Malin, G., Law, C. S., Watson, J., Liss, S., and Liddicoat, I. (2000). In situ evaluation of air-sea gas exchange parameterizations using novel conservtauve and volatile tracers. Global Biogeochem. Cycles, 14(1):373-387.

Palter, J. B., Marinov, I., Sarmiento, J. L., and Gruber, N. (2013). Large-Scale, Persistent Nutrient Fronts of the World Ocean: Impacts on Biogeochemistry. In Belkin, I. M., editor, Chem. Oceanogr. Front. Zo., pages 41-53. Springer Publishing.

Pelegrí, J., Arístegui, J., Cana, L., González-Dávila, M., Hernández-Guerra, A., Hernández-León, S., Marrero-Díaz, A., Montero, M., Sangrà, P., and Santana-Casiano, M. (2005). Coupling between the open ocean and the coastal upwelling region off northwest Africa: water recirculation and offshore pumping of organic matter. J. Mar. Syst., 54(1-4):3-37.

Pelegrí, J. L., Marrero-Díaz, A., and Ratsimandresy, A. W. (2006). Nutrient irrigation of the North Atlantic. Prog. Oceanogr., 70(2-4):366-406.

Pelegrí, J. L. and Peña-Izquierdo, J. (2015). Eastern boundary currents off North-West Africa. In Valdés, L. and Déniz-González, I., editors, Oceanogr. Biol. Featur. Canar. Curr. Large Mar. Ecosyst., IOC Technical Series, pages 81-92. IOC-UNESCO, Paris.

Pérez, F. F., Mintrop, L., Llinás, O., González-Dávila, M., Castro, C. G., Alvarez, M., Körtzinger, A., Santana-Casiano, M., Rueda, M. J., and Ríos, A. F. (2001). Mixing analysis of nutrients, oxygen and inorganic carbon in the Canary Islands region. J. Mar. Syst., 28(3-4):183-201.

Pérez-Hernández, M. D., Hernández-Guerra, A., Fraile-Nuez, E., Comas-Rodríguez, I., Benítez-Barrios, V. M., Domínguez-Yanes, J. F., Vélez-Belchí, P., and De Armas, D. (2013). The source of the Canary current in fall 2009. J. Geophys. Res. Ocean., 118(6):2874-2891.

Pérez-Rodríguez, P., Pelegrí, J. L., and Marrero-Díaz, A. (2001). Dynamical characteristics of the Cape Verde frontal zone. Sci. Mar., 65(S1):241-250.

Reynolds, S., Mahaffey, C., Roussenov, V., and Williams, R. G. (2014). Evidence for production and lateral transport of dissolved organic phosphorus in the eastern subtropical North Atlantic. Global Biogeochem. Cycles, 28(8):805-824.

Rintoul, S. R. and Wunsch, C. (1991). Mass, heat, oxygen and nutrient fluxes and budgets in the North Atlantic Ocean. Deep Sea Res. Part A. Oceanogr. Res. Pap., 38, Sup.1:S355-S377.

Roussenov, V., Williams, R. G., Mahaffey, C., and Wolff, G. A. (2006). Does the transport of dissolved organic nutrients affect export production in the Atlantic Ocean? Global Biogeochem. Cycles, 20(3):1-14. 
Sangrà, P., Pascual, A., Rodríguez-Santana, Á., Machín, F., Mason, E., McWilliams, J. C., Pelegrí, J. L., Dong, C., Rubio, A., Arístegui, J., Marrero-Díaz, Á., Hernández-Guerra, A., Martínez-Marrero, A., and Auladell, M. (2009). The Canary Eddy Corridor: A major pathway for long-lived eddies in the subtropical North Atlantic. Deep Sea Res. Part I Oceanogr. Res. Pap., 56(12):2100-2114.

Santana-Falcón, Y., Álvarez-Salgado, X. A., Pérez-Hernández, M. D., Hernández-Guerra, A., Mason, E., and Arístegui, J. (2017). Organic carbon budget for the eastern boundary of the North Atlantic subtropical gyre: major role of DOC in mesopelagic respiration. Sci. Rep., 7(1):10129.

Santana-Falcón, Y., Benavides, M., Sangrà, P., Mason, E., Barton, E. D., Orbi, A., and Arístegui, J. (2016). Coastal-offshore exchange of organic matter across the Cape Ghir filament (NW Africa) during moderate upwelling. J. Mar. Syst., 154:233-242.

Sarmiento, J. L. and Gruber, N. (2006). Ocean Biogeochemical Dynamics. Princeton University Press.

Schlosser, C., Klar, J. K., Wake, B. D., Snow, J. T., Honey, D. J., Woodward, E. M. S., Lohan, M. C., Achterberg, E. P., and Moore, C. M. (2014). Seasonal ITCZ migration dynamically controls the location of the (sub)tropical Atlantic biogeochemical divide. Proc. Natl. Acad. Sci., 111(4):14381442 .

Serret, P., Robinson, C., Aranguren-Gassis, M., García-Martín, E. E., Gist, N., Kitidis, V., Lozano, J., Stephens, J., Harris, C., and Thomas, R. (2015). Both respiration and photosynthesis determine the scaling of plankton metabolism in the oligotrophic ocean. Nat. Commun., 6:1-9.

Stramma, L. (1984). Geostrophic transport in the Warm Water Sphere of the eastern subtropical North Atlantic. J. Mar. Res., 42(3):537-558.

Tomczak, M. (1981). An analysis of mixing in the frontal zone of South and North Atlantic Central Water off North-West Africa. Prog. Oceanogr., 10(3):173-192.

Torres-Valdés, S., Roussenov, V. M., Sanders, R., Reynolds, S., Pan, X., Mather, R., Landolfi, A., Wolff, G. A., Achterberg, E. P., and Williams, R. G. (2009). Distribution of dissolved organic nutrients and their effect on export production over the Atlantic Ocean. Global Biogeochem. Cycles, 23(4):1-16.

Treguer, P. and Le Corre, P. (1979). The ratios of nitrate, phosphate, and silicate during uptake and regeneration phases of the Moroccan upwelling regime. Deep Sea Res. Part A, Oceanogr. Res. Pap., 26(2):163-184.

Valdés, L. and Déniz-González, I., editors (2015). Oceanographic and biological features in the Canary Current Large Marine Ecosystem. Number 115. IOC-UNESCO, Paris.

Vélez-Belchí, P., Pérez-Hernández, M. D., Casanova-Masjoan, M., Cana, L., and Hernández-Guerra, A. (2016). On the seasonal variability of the Canary Current and the Atlantic Meridional Overturning Circulation. J. Geophys. Res. Ocean., 122:4518-4538. 
Vidal, M., Aspillaga, E., Teixidor-Toneu, I., and Delgado-Huertas, A. (2018). Lateral Transport of N-Rich Dissolved Organic Matter Strengthens Phosphorus Deficiency in Western Subtropical North Atlantic. Global Biogeochem. Cycles, 32(9):1350-1366.

Visbeck, M., Marshall, J., Haine, T., and Spall, M. (1997). Specification of Eddy Transfer Coefficients in Coarse-Resolution Ocean Circulation Models*. J. Phys. Oceanogr., 27:381-402.

Walsh, J. J. (1991). Importance of continental margins in the marine biogeochemical cycling of carbon and nitrogen. Nature, 350(6313):53-55.

Wanninkhof, R., Asher, W. E., Ho, D. T., Sweeney, C., and Mcgillis, W. R. (2009). Advances in Quantifying Air-Sea Gas Exchange and Environmental Forcing. Ann. Rev. Mar. Sci., 1:213-244.

Wanninkhof, R., Mcgillis, W. R., Oceanographic, W. H., and Hole, W. (1999). A cubic relationship between air-sea CO2 exchange and wind speed. Geophys. Res. Lett., 26(13):1889-1892.

Wanninkhof, R. H. (1992). Relationship between wind speed and gas exchange. J. Geophys. Res., 97(92):7373-7382.

Woolf, D. K. and Thorpe, S. A. (1991). Bubbles and the air-sea exchange of gases in near-saturation conditions. J. Mar. Res., 49:435-466.

Wu, J., Sunda, W., Boyle, E., and Karl, D. (2000). Phosphate depletion in the western North Atlantic Ocean. Science (80-. )., 289:759-763.

Zamora, L. M., Landolfi, A., Oschlies, A., Hansell, D., Dietze, H., and Dentener, F. (2010). Atmospheric deposition of nutrients and excess N formation in the North Atlantic. Biogeosciences, 7(5):777-793.

Zenk, W., Klein, B., and Schroder, M. (1991). Cape Verde Frontal Zone. Deep Sea Res. Part A. Oceanogr. Res. Pap., 38:S505-S530.

Zweng, M. M., Reagan, J., Antonov, J., Mishonov, A., Boyer, T., Garcia, H., Baranova, O., Johnson, D., Seidov, D., and Bidlle, M. (2013). World Ocean Atlas 2013, Volume 2: Salinity. NOAA Atlas NESDIS, 2(1):39. 


\section{Appendix A Supplementary Figures}
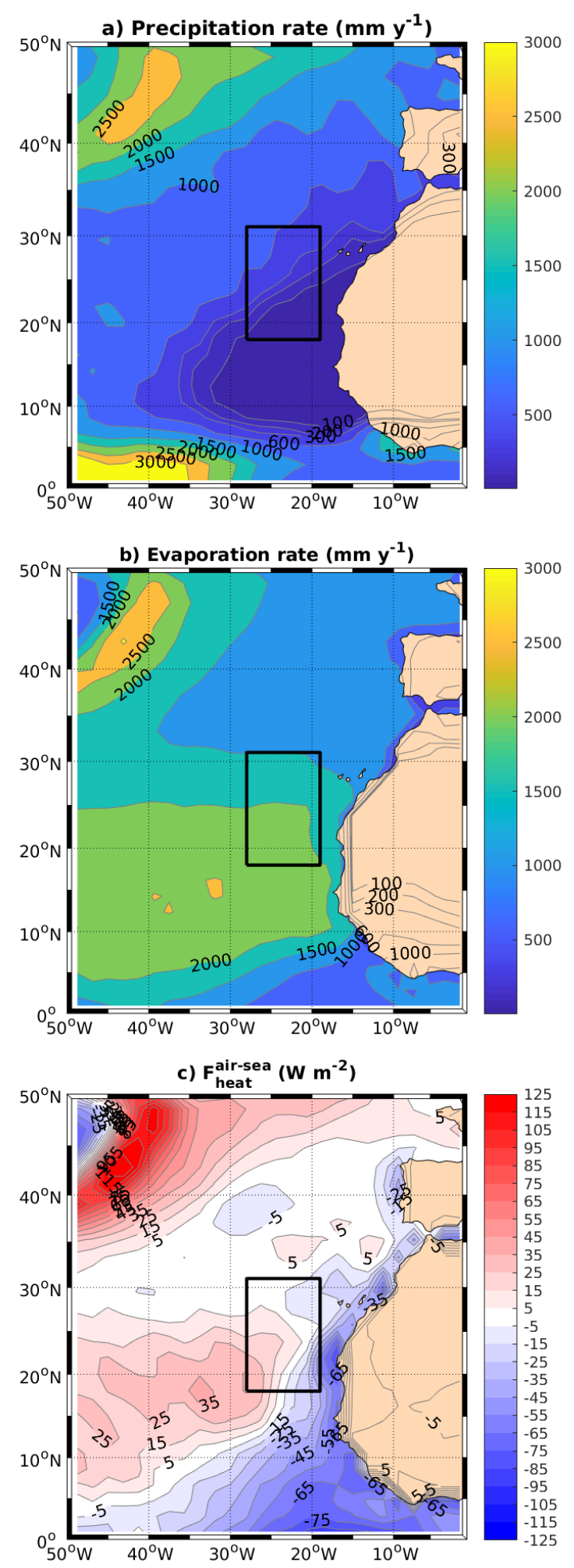

Supplementary Figure A1: (a) Evaporation, (b) precipitation and (c) net heat flux in the eastern North Atlantic derived from the NCEP/NCAR Reanalysis monthly climatologies provided by NOAA/OAR/ESRL PSD https: //www.esrl.noaa.gov/psd/) 